Florida International University

FIU Digital Commons

$8-1983$

\title{
A study to determine the basic requirements of international hotel chains when investing in Latin America, and also to analyze if Colombia meets these basic requirements
}

Carlos Alberto de Freitas

Florida International University

DOI: $10.25148 /$ etd.FI15101446

Follow this and additional works at: https:// digitalcommons.fiu.edu/etd

Part of the Hospitality Administration and Management Commons

\section{Recommended Citation}

Freitas, Carlos Alberto de, "A study to determine the basic requirements of international hotel chains when investing in Latin America, and also to analyze if Colombia meets these basic requirements" (1983). FIU Electronic Theses and Dissertations. 3416.

https://digitalcommons.fiu.edu/etd/3416 


\section{ABSTRACT}

A Study to Determine the Basic Requirements of International Hotel Chains When Investing in Latin America, and also to Analyze if Colombia Meets These Basic Requirements by

Carlos Alberto De Freitas

1. Area of Investigation

The basic requirements of six major International Hotel chains when investing in Latin America, and the Colombian laws which deal with Foreign Investment, in order to find out the reasons why there are only two major chains in Colombia.

2. Materials and Methods Used

One questionnaire directed to the Directors of Operations of the six selected international hotel companies was used to collect the required data as well as in depth personal interviews. The data gathered in relation to the Colombian laws came from official publications and Colombian law codes.

3. Major Findings

A. International hotel chains do want to expand overseas, but without any commitment of funds.

B. The requirements of the International Hotel chains are more strict when the companies want to invest in Latin 
America.

C. Feasibility studies done by the international hotel chains are more in depth and more carefully done for Latin America than anywhere else.

D. International hotel chains are very interested in Colombia as a country to be in.

E. Colombian laws are becoming more and more liberal towards foreign investment.

F. The main reason for Colombia not having more international hotel chains is because local investors want a quick return on their investment.

4. Results and Conclusion

A. Colombia is a good country to invest in.

B. The Colombian Government must help the local investors by means of allowing them to have easy access to credit.

C. Colombia has to create more incentive to attract more foreign investors.

D. Colombia has to get its Tourism Industry out of the Andean Pact in order to be more liberal towards foreign investment. 


\title{
A STUDY TO DETERMINE THE BASIC REQUIREMENTS OF INTERNATIONAL HOTEL CHAINS WHEN INVESTING IN IATIN AMERICA, AND ALSO TO ANALYZE IF COLOMBIA MEETS THESE BASIC REQUIREMENTS
}

\author{
by \\ Carlos Alberto De Freitas
}

A thesis submitted in partial fulfillment of the requirements for the degree of

\author{
MASTER OF SCIENCE \\ in \\ SCHOOL OF HOSPITALITY MANAGEMENT \\ at \\ FLORIDA INTERNATIONAL UNIVERSITY \\ Chairperson
}

Committee in charge:

Professor Donald Greenaway

Dean Anthony G. Marshall

Professor Steven Moll 
To Professors Donald Greenaway and Steven Moll

This thesis, having been approved in respect to form and mechanical execution is referred to you for judgment upon its substantial merit.

Dean Anthony G. Marshall

School of Hospitality Management

The thesis of Carlos Alberto De Freitas is approved.

Donald Greenaway

Distinguished Professor

Steven V. Moll

Assistant Professor

Date of Examination: August 1983 
A STUDY TO DETERMINE THE BASIC REQUIREMENTS OF INTERNATIONAL HOTEL CHAINS WHEN INVESTING IN LATIN AMERICA, AND AISO TO ANALYZE IF COLOMBIA MEETS THESE BASIC REQUIREMENTS

by Carlos Alberto De Freitas

A thesis submitted in partial fulfillment of the requirements for the degree of MASTER OF SCIENCE
in
SCHOOL OF HOSPITALITY MANAGEMENT
at
FLORIDA INTERNATIONAL UNIVERSITY 


\section{ACKNOWLEDGEMENTS}

This research could not have been prepared without the guidance and assistance of Dr. Donald Greenaway, visiting distinguished professor, and of Professor Steven Moll, both at School of Hospitality Management, Florida International University.

My deep appreciation to Dr. Greenaway, who guided me through all stages of this research and to the final accomplishment, and to Professor Moll for his time, assistance, and encouragement.

An additional acknowledgement is due to Dr. William J. Morgan, for his guidance and assistance during two academic years at Florida International University. 


\section{DEDICATION}

This thesis is especially dedicated to my parents and to my girlfriend for their continuous patience, support and understanding without which this study would not have been possible. 
CHAPTER I: THE PROBLEM AND ITS SETTING

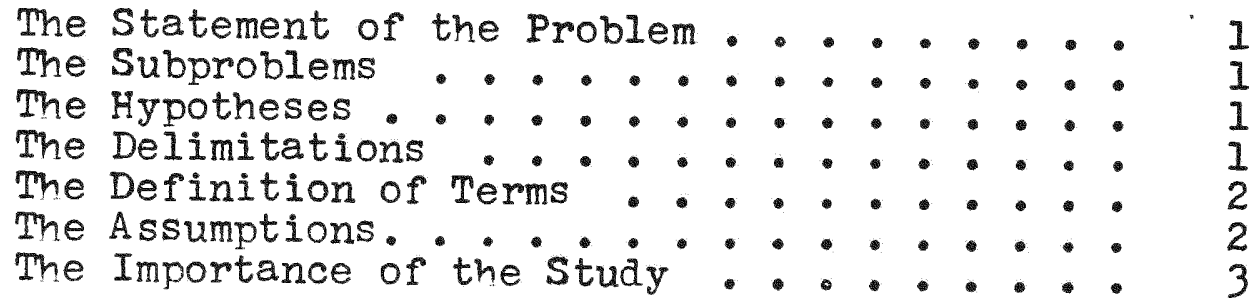

CHAPTER II: THE REVIEW OF THE RELATED LITERATURE

History and Development of International Hotel

International Hotel companies : : : : : : 5

The First Inter-Continental Hotel : : : 9

Methods of Compensation for International

Hotel Chains . . . . . . . 15

Colombia's Generai Outlook: : : : : : : 16

Economy . . . . . . . . : 18

Projections for 1982 : : : : : : 23

Foreign Investment in Colombia: : : : : 24

Tourism in Colombia ......... 26

Colombian Government Tourist Office: : : : 29

Hotel Industry in Colombia...: 30

CHAPTER III: THE DATA AND THE TREATMENT OF THE DATA

The Data

The Primary Data........... 33

The Secondary Data....... 33

The Criteria for the Admissibility of the Data 33

The Research Methodology ........ 34

The Specific Treatment of the Data for Each

Subproblem ............... 34

Subproblem one : : : : : : : 34

The Data Needed ........ 34

The Location of the Data: . . : : 34

The Means of Obtaining the Data: : : 34

The Treatment of the Data ...... 35

Subproblem Two ............ 35

The Data Needed ........ 35

The Location of the Data: : : : : 35

The Means of Obtaining the Data : : : 36

The Treatment of the Data : : : : 36 
CHAPTER IV: THE REQUIREMENTS OF THE INTERNATIONAL HOTEL CHA INS

The Sheraton Corporation . . . . . . 37

Criteria Established Prior to Expansion

Overseas................ 39

Criteria Used for Development Overseas: : 42

Contracts ........................ 46

Lease Arrangements ........ 49

Relations with Local Governments : . . : 50

Inter-Continental Corporation ..... 51

Criteria Established Prior to Expansion

Overseas

Criteria Used for Development Overseas :

Contracts ................

Lease Arrangements . . . . . . . . :

Relations with Local Governments . . .

Extent of Restrictions Placed by Local

Governments ...............

Hyat International : : : : : :

Criteria Established Prior to Expansion

Overseas

Financial Aspects . . . . . . : :

Management Contracts :. : . : : :

Franchising and Lease Arrangements . . .

Relations with Local Governments . . . .

Holiday Inn Corporation .........

Criteria Established Prior to Expansion

Overseas ................ 76

Financial Aspects . . . . . . . 77

Relations with Local Governments . . . 78

Hilton International Corporation . . . . 79

Criteria Established Prior to Expansion

Overseas .............. 79

Financial Aspects . . . . . . . . 80

Corporate Strategy :. : . : : : 81

Management Contracts

Relations with Local Governments : : . 82

Marriott Corporation ....... 84

Criteria Established Prior to Expansion

Overseas

Financial Aspects $\cdot$. $^{\circ} \cdot$. $^{\circ} \cdot$. $^{\circ} \cdot$.

Contracts

Lease Arrangements ...........

Relations with Local Governments . . . 
CHAPTER V: FOREIGN INVESTMENT IN COLOMBIA

Page

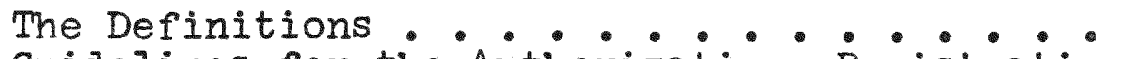

Guidelines for the Authorization, Registration, and Control of Foreign Investments

Obligation to Register the Investment: : 102

Net Value of the Investment ......... 104

Transfer of Profits ............ 105

Reinvestment of Profits:...: 107

Investment of Excess Profits . : : : 107

Re-exportation of Capital . . . . . . : 108

Control Over the Investment : : : : : 111

Foreign Credit ............. 113

Domestic Credit:. : . : 116

Requirements for the Approval of Foreign Investments in the Tourism Sector......

CHAPTER VI: PROOF OF THE HYPOTHESES, CONCLUSIONS, AND RECOMMENDATIONS

First Hypothesis . . . . . . . 119

Second Hypothesis . . . . . . . . 120

Conclusions International Hotel Companies. 122

Conclusions of Colombian Laws and Foreign Investment ......................... 124

Major Conclusions : : : : : : : : 127

Recommendations . . . . . . . . . . 129

A PPENDICES

Appendix A: The Cover Ietter of the Mailed Questionnaire ...... 132

Questionnaire ...... 133

Appendix B: Decree Law 444 March 22, 1967. 138

BIBLIOGRAPHY . . . . . . . . . . 139

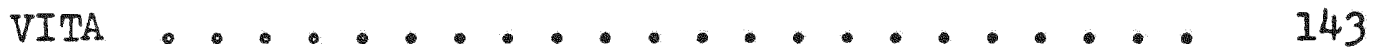




\section{LIST OF TABLES}

Page

Table 1: Direct Foreign Investment in Colombia 25

Table 2: Purpose of Travel to Colombia... 28

Table 3: Supply of Rooms in Colombia by Main Departments. . . . . 30

Table 4: Supply of Rooms in the Different Hotel Categories........ 31

Table 5: Percentage of Variation in Room Supply Between 1977-1978....... 31

Table 6: Number of Rooms in Five, Four, and Three Star Hotels in the Four Most Important Tourist Centers in Colombia 31 
CHAPTER I

THE PROBLEM AND ITS SETTING

The Statement of the Problem

The purpose of this study is to determine the basic requirements of International Hotel chains when investing in Latin America, and also to analyze if Colombia meets these basic requirements.

The Subproblems

1. The first subproblem. The first subproblem is to determine the basic requirements of the International Hotel chains when investing in Latin America.

2. The second subproblem. The second subproblem is to analyze if Colombia meets the basic requirements of the International Hotel chains.

The Hypotheses

The first hypothesis is that International Hotel chains have certain requirements when investing in Latin America.

The second hypothesis is that Colombia does not meet the basic requirements by the International Hotel chains. The Delimitations

The study will consider the investing requirements 
in Latin America.

The study will only consider the investing requirements of International Hotel chains (Hilton International, Sheraton, Holiday Inn, Hyatt International, Marriott and Inter-Continental).

The study will be limited to the companies that have been mentioned above, and the reasons why, only two of them (Hilton and Inter-Continental), had invested in Colombia and the others have not.

The Definition of Terms

International Hotel chains: Assuming that these chains can be considered as Multinationals, then they are corporations that participate in intermational business activities. A firm that produces, markets, and finances its operations throughout various nations of the world.**

Assumptions

The first assumption. The first assumption is that International Hotel chains will continue to invest and expand.

The second assumption. The second assumption is that Intermational Hotel chains are interested in Latin America and specifically in Colombia as a potential market with good growth opportunities.

* Jerry M. Rosenberg. Dictionary of Business and Management (A Wiley-Interscience Publication) p. 292. 
The third assumption. The third assumption is that Colombia is interested in attracting more International Hotel chains.

The fourth assumption. The fourth assumption is that the economy and the political situation in Colombia will remain reasonably stable.

The Importance of the Study

The importance of this study can be viewed from two different sides. From one side the importance to the International Hotel chains, and from the other side the importance to Colombia.

First of all then, this study is important in that it will help the researcher know which are, if any, the basic requirements of the International Hotel chains when investing in Latin America. Furthermore, if these basic requirements vary from one part of the world to another, or if on the other hand, they are the same all over the world.

Second of all, this study is important because it will give an idea to the researcher of how important Latin America is for the International Hotel chains, and how do they view Latin America in their long run plans.

Finally, the study will help the researcher find out the reasons why, at the present time, there are only two major International Hotel chains in Colombia.

On the other hand, this study will help determine which of the basic requirements, Colombia does not have in 
order to attract more International Hotel chains.

Additionally, the study will give the researcher an idea of how does Colombia view its tourism potentials, and if the Colombian Govermment has any specific plans towards the development of the Tourism Industry.

Furthermore, by means of this study the researcher will be able to know what is the image that the International Hotel chains have of Colombia as a market with a good potential for tourism or not.

The study will become even more important when the researcher analyzes some of the points mentioned above, and gets some conclusions on whether or not Colombia should be more flexible in its requirements towards foreign investment. 
CHAPTER II

THE REVIEW OF THE RELATED LITERATURE

\section{HISTORY AND DEVELOPMENT OF INTERNATIONAL}

HOTEL CHA INS

"In Asia, starting about 500 B.C., along the caravan routes Caravanserais were found in the country and Khans in the cities. Caravanserais provided lodging only and were maintained as charities by the local mogul. There was a porter who might receive gratuities from the traveler. The Khans, on the other hand, provided lodging, food and other necessaries, and charged a fixed rate decided by the Govemor."I

In the 13th century China, the Mongols established relay houses to accommodate travelers and provide postal services.

The Roman Catholic Church was perhaps the first international hotel chain. Monasteries or Abbeys operated hospices at key points along the road, as well as guest houses adjacent to the church building if located in a remote area. Guests were also accommodated within the main buildings themselves. However, the guests were expected to supply their own food, fuel, and bedding.

IStatler, Lectures. Presented at the University of Massachusetts. Department of Hotel, Restaurant and Travel Administration, 1971 , p. 62. 
Increase in Hotel Construction

With the advent of general travel by rail, hotel construction increased greatly in Europe and the United States. Individual hotel managers started seasonal operations in two countries. A European manager might operate a hotel in Switzerland in the summer and in Southem France or Italy in the winter season, sometimes for the same owners.

"Probably the most famous of these international hotel-keepers was Cesar Ritz (1850-1917)。 His first such international management experience was at the age of 26 , managing the Rigi Kulm Hotel in Switzerland and the Hotel Victoria at San Remo. During the 1890's, Ritz was administratively and financially active in the planning or operation of seventeen hotels and restaurants located in Egypt, South Africa, Spain, Italy, France, Switzerland, Germany, and England; and he was engaged in investment negotiations and discussions for new hotels in Portugal, Argentina, Hungary, Canada and the United States."2

"Probably the first referral services, besides Thomas Cook and Sons which was established in 1844, was the British Register of Inspected and Approved Hotels issued by the Bicycle Touring Club in 1878." 3

$$
2_{\text {Ibid., pp. 62-63. }}
$$

3 Peter Michael. Intemational Tourism (Iondon: Hutchinson and Co., Ltd., 1969) p. I20. 
Centralization of Control

At the time that E.M. Statler was establishing his Inside Inn at the St. Louis Exposition, country trust associations in England, Scotland, Ireland, and Wales were reforming the public houses to serve better the traveler. Gradually one association joined with another; and in 1919 Trust Houses Limited, was formed to provide centralized control, inspection of local managers, and fixed and reasonable prices. Catering was encouraged, as was expanding the number of rooms. The benefits of centralization enable the inns to operate free of ties to a specific brewery for supply of alcoholic refreshments.

"Incidentally, brewers in England, Europe, Australia, and New Zealand have operated taverns, public houses, and inns for several centuries to ensure outlets for their products." 4 Like modern governments, the brewers supplied the capital for construction, technical advice, and inspection services.

"The first American international hotel operator was probably Eugene C. Epply during the twenties and thirties. Based in Omaha, he operated three hotels in Central America as well as a number of midwest (U.S.) properties. In the thirties, the American Hotel Corporation operated two hotels in Panama and one in the Dominican Republic." 5

\footnotetext{
${ }^{4}$ Statler, op. cit., p. 63.

5 Ibid.
} 
Hotel construction in Europe and in North America was stimulated by the prosperity of the twenties. Dr. Lundberg has indicated that hotels are built for: ${ }^{6}$

- Pride of ownership

- Profit from building expenditures

- Profit from promoting and financing

- Profit from appreciation in value of site and of the surrounding property

- To reduce income taxes

To this list of reasons might be added the following:

- To serve as part of a larger (entertainment) development

- To sell products and services in the future as represented by franchising systems and "tied houses"

- Profit or salary for managing operations (such as Trader Vic's or hotel owning company managers)

- Profit from sale of land to hotel company

- To generate sales for other hotels (in chains) or modes of transport.

International Hotel Companies

Multi-unit North American hotel companies emerged in the twenties, and their very size forced standardization of design, operations and control methods. Some of the operational techniques were made available to all American

6Donald E. Lundberg. The Hotel and Restaurant Business, p. 71 . 
hotels by the American Hotel Association's publications. After World War II, American hotel executives and companies were in the best economic position to expand overseas, aided by the principles and legislation of the Marshall Plan.

It was at this time that Pan American World Airways organized the Inter-Continental Hotel Corporation. The company began as the inspiration of two visionaries, Franklin Delano Roosevelt, then President of the United States, and Juan Terry Trippe, former President of Pan American Airways. At a White House breakfast one day in 1944, the two discussed a concern for the development of South America. Out of the meeting came a practical conclusion--one way to attract businessmen and tourists would be to offer them good hotels. Trippe agreed that Pan Am, with the support of such U.S. institutions as the ExportImport Bank, could form a subsidiary to foster endeavor; and in April 1946, Intermational Hotels Corporation was born, only to change its name the following year to InterContinental Hotels Corporation, which has been printed since 1964 to further the corporate image as "Inter-Continental."

\section{The First Inter-Continental Hotel}

The organization started out by remodeling, and taking over the management of existing hotels. Inter-Continental's first hotel (which was sold and closed in 1967) was the Grande in Belem, Brazil, at the mouth of the Amazon River. Under the corporation's original policy, hotels were to be 
situated along Pan American's routes, and Belem was a stop on the airline's flying boat run across the northeastem shoulder of South America. Belem can be steaming hot, and after Inter-Continental's refurnishing, the Grande's cocktail lounge was the only air-conditioned public room in town.

Following face-liftings were more elaborate. Under Inter-Continental operation, the Hotel Carrera in Santiago, Chili, was changed figuratively from caterpillar to butterfly. "As a result, room occupancy jumped from 49 percent in 1959 to 74 percent in 1953. Food and Beverage sales and other peripheral income rose from 122 percent of room sales in 1950 to 156 percent in 1953."?

Similarly, the 250-room Hotel Del Prado in Barranquilla, Colombia, before joining Inter-Continental, had the fading charm of an Old World grande dame. Inter-Continental restored her youth and added a soda fountain and a snack bar by the swimming pool. The nightclub was redecorated; and after dark, newly installed floodlights illuminated the hotel's swaying palms, while famous bands played on the terrace.

Soon Inter-Continental was breaking ground for new hotels. The corporation generally preferred associations with local investors having majority control, Inter-Continental providing minority financial interest and a

7statler, op. cit., p. 64. 
management contract. It assumed the major responsibility for designing and promoting the new hotels that would bear the Inter-Continental name; and in so doing, brought about radical innovations in the concept of what a hotel in a "foreign land" could be.

A principal influence in this regard was InterContinental's second President, Byron E. Calhoun. A veteran hotelier, Calhoun had definite ideas about the function and design of Inter-Continental hotels. Their aura, he felt, should be one of informal, distinctive luxury. There should be a grill, a coffee shop and a snack bar, all places where guests could get quick service at reasonable prices. There was also to be a formal dining room, with dancing and evening entertainment. If guests wished to wear dinner clothes, fine; but formal attire, as in "British Colonial" hotels, was not to be required. He had noted that the less formal establishments were doing the greater business.

The combination parlor and bedroom, typical of traditional hotels, was replaced by an attractive, air conditioned living room with a picture window, and a divan that converted to a bed. This provided patrons with two rooms for the price of one.

Large trunk closets were eliminated as travelers no longer arrived by ship with luggage for an entire season. They now came by plane, with compact suitcases that held clothing for a few days. The old-fashioned, high-ceilinged hotel lobby, with its omate walls, was also deemed a space- 
waster. The modem lobby's function was that of a thoroughfare for busy travelers, not a dawding place. The InterContinental lobby ceilings were lower, making available more room space above. Lobby walls were converted into shops, airline and cable offices, plus other facilities that provided conveniences to the guests and income to the hotel. Inter-Continental's new hotels began to embellish the Latin American landscape with a contemporary elegance that the region had never known. "The first hostelry designed and constructed by Inter-Continental was Bogotá's Tequendama - a 400-room, \$8,725,000 modern palace with wall to wall carpeting and high-speed elevators." 8 The 150-room $\$ 3,000,000$ Hotel Del Lago, in Maracaibo, Venezuela, featured a swimming pool with a window through which non-swimmers could watch the underwater ballet.

Nonetheless, along with modern comforts, Inter-Continental insisted that each hotel preserve the unique charms and decor of the host country. Guests should not travel thousands of miles and step into the atmosphere of a Miami Beach resort. This policy is still honored in Inter-Continental's current marketing slogan, "When you have seen one, you haven't seen them all!"

In all of its facilities, Inter-Continental strove to preserve local tradition. As part of its effort, it built its kitchens backward. Instead of first constructing the kitchen, and then turning out the meals that it could

${ }^{8}$ Gen. Hernan Medina. Historia del Hotel Tequendama. (Bogotá: Editorial Norma, 1974), p. 40 . 
best produce, Inter-Continental observed the types of local preferences in cuisine, then built the kitchens around the local menus and available foods.

From the beginning, Inter-Continental staffed its hotels with as many local citizens as possible. Admittedly, this practice presented problems. Some locally hired waiters thought that fast breakfast service meant putting fruit, cereal, bacon and eggs, and a second cup of coffee, all on the table at once. "In Caracas's Tamanaco, a telephone operator became so excited upon handling her first call from overseas that she deserted her switchboard and ran through the lobby paging the recipient." 9 Inter-Continental alleviated such employee inexperience by starting personnel training programs that have developed into a global educational curriculum.

For all of its trials and tribulations, Inter-Continental's pioneering enterprise bloomed; and unprecedented numbers of tourists and businessmen went south of the border. By 1960, the chain had 11 properties in Latin America for an expansion rate of almost one hotel per year. The vast majority of new hotels opened in the principal cities of the world since 1957 are associated with international hotel companies, increasingly in cooperation with airlines, or as a result of airline leadership. Thus, these companies are making a powerful contribution to economic growth through the encouragement and facilitation of tourism. 
Wile initially there was a tendency to export "an American hotel" overseas, most U.S. international corporations today attempt to embody in each hotel's design some of the cultural traditions of the host country, so that each hotel will be representative of the country in which it is located. Local investors are not always sympathetic with these efforts. They frequently demand, apparently for reasons of status, a "modern" hotel, which to them means "North American."

The chief contributions that international hotel companies can make to an operation of individual hotels include:

- Their experience in development and funding of projects

- Possible equity investment in the property

- Profit-generating design criteria and techniques

- Technical services in construction, decoration and equipment

- A manpower pool of trained executives and supervisors

- World-wide personnel recruiting services

- Training know-how and materials

- Uniform systems of economical operating techniques

- Impartial application of standaras and controls

- World-wide advertising

- World-wide reservations and sales organizations 
- World-wide private network of telecommunications

- Identification in the world travel market

- Reservation referrals from one hotel to another

- Some sharing of risks

- Shared benefits of good business practices.

- Logistical support by home office and regional staffs composed of trained executives

- Group buying benefits

Methods of Compensation for International Hotel Chains

Methods of compensation to the International Hotel company include incentive fees or participation in profits, or a fixed lease rental income, or a fixed management fee, or a franchise fee, plus special charges for technical or managerial services, possibly a fixed charge per reservation or room night, perhaps in the form of reimbursement of system expenses.

In 1971, hotel companies operating internationally included:

- Braniff Airlines

- Esso Motor Hotels

- European Hotel Corp. (several airlines)

- Flagship Hotels (American Airlines)

- Grand Metropolitan Hotels

- Hilton Intemational

- Holiday Inns

- Howard Johnson 
- Hyatt International

- Inter-Continental Hotels

- Knott Hotels Corp.

- Loew's Hotels

- D.W. Ludwig Interests

- Marriott Corporation

- Rockresorts Company (Eastern Airlines)

- Sheraton International

- Sonesta Hotels Corp.

- Steigenberger Hotels Lta.

- Travelodge International

- Trust Houses/Forte Lta.

- Western Hotels International (United Airlines)

Colombia's General Outlook

During the l6th century, Spanish conquistadores marched up the Valley of the Magdalena River into the Andes mountains. They hoped to find gold. Legend told of El Dorado, an Indian king who took part in a dramatic ceremony. His attendants powdered him with gold dust, then rowed him into a lake. He submerged himself, and his subjects tossed in emerald and gold ornaments as offerings to the gods.

Today Colombia with more than 600 mines, is a leading producer of gold in South America. Most mines lie near the country's second largest city, Medellín. Colombia also produces 90 percent of the world's emeralds. The green 
crystals come from mines near Bogotá. No dynamite blast and mountain-eating machinery. Workers chip away at the thin veins with hand tools, just as Indians did centuries ago. In the capital and largest city, the gold museum displays a 1796 karat emerald, the size of a woman's fist. For all its gold and emeralds, however, Colombia's real treasure is coffee. Some 300,000 farms, of about fifteen acres each, cling to the slopes of the Andes. In the shade of banana trees, the berries of the coffee trees slowly ripen, turning from dark green to yellow to bright red. After three weeks, they removed the skins and pack the coffee beans into large sacks.

If you stood at the foot of an imaginary mountain with a telescope, you could see sugar cane and cotton fields in the low lands, coffee trees in the cool slopes above 3,000 feet, and potatoes in the colder regions above 6,500 feet.

Even though western Colombia contains steep terrain, the majority of Colombians live there. Farm villages cling to alpine ridges, and modern cities seemed to crawl up the sides of valleys.

Colombia, the fourth largest country in South America, has an area of 444,000 square miles, about the size of Texas and California combined. With a population of about twenty-seven million, it ranks second in South America, after Brazil, in number of inhabitants. Two thirds of the population is concentrated in the country's highland regions 
covering roughly one third of the country. By contrast, the eastern regions are scarcely populated.

Most prominent in Colombia's topography are the three ranges of the Andean Mountain chain. The Pacific Ocean coast line is nearly 800 miles long, and the Atlantic, or Caribbean, some 1,000 miles. Crossed by the Equator, Colombia has four distinct climatic zones depending on altitude: tropical, moderate,cool and cold. Bordering nations to the South are Ecuador and Perú; to the East Venezuela and Brazil; and to the Northwest Panama.

\section{Economy}

Colombia has attained a solid foreign exchange position, with large reserves and an excellent credit rating. The current level of international reserves exceeds the yearly value of imports or, seen in other terms, the outstanding balance of the entire foreign debt of Colombia. Expansion in exports of merchandise and services has largely contributed to this unprecedented rise in the level of international reserves. There is now greater diversification in exports, with coffee representing some 60 percent of the total value; semi-manufactured and manufactured items some 20 percent; foodstuffs other than coffee 10 percent; fossil fuels 4 percent; and other basic products 6 percent. Among services, tourism has come to play a relevant role with a yearly inflow of about $\$ 700$ million. 
Following five successive years of dynamic growth, Colombia's export trade contracted by about 27 percent in value terms for the period January-November 1981. The main factor in this decline was coffee. Exports other than coffee amounted to $\$ 1.425$ billion through the end of 1981 , just under the $\$ 1.436$ billion recorded in 1980. Many agricultural commodities performed well and the overall value of these exports remained as in 1980. Of particular dynamism were bananas, frozen beef, rice, beans and cacao, Which emerged as an export for the first time in a decade. Fresh cut flowers and cotton fiber showed moderate growth, but sugar, tobacco, and cheeses were off sharply.

The entire volume of foreign trade, including imports and exports, reached close to $\$$ \%illion in 1980, a record high. Colombia's key trade partners are Europe, the U.S. and Latin America, particularly Andean Group nations. Exports to Europe are newly vigorous, and this area now exceeds North America as a market for Colombian goods.

Colombia's financial liquidity enables it to obtain the necessary foreign financing for its larger development projects. Foreign credits will cover approximately 50 percent of the 1981-1984 investment program, some $\$ 10.6$ billion out of a total \$19.4 billion package.

The private foreign investor is also finding Colombia's business opportunities attractive. On the basis of Joint Venture agreements, large scale coal and nickel 
mining projects are underway, and the search and development of new oil and gas deposits is picking up rapidly. About 71 percent of the outstanding book value of foreign investment is associated with manufacturing. Foreign investment is associated with manufacturing. Foreign investment in manufacturing rose by 31 percent between 1978-80 just ahead of the 26 percent increase registered in overall foreign investment. This spurt is investment activity follows a relatively slow period in the early seventies and is indicative of Colombia's highly stimulative policy of recent years.

The Colombian economy in 1981 registered a moderate GDP growth rate of 3 to 3.5 percent per annum, compared with growth rates between 4 and 8.9 percent per annum for the previous five years. The projected improvement in the world economic picture for the second half of 1982 should help Colombia's economy resume a faster growth pace.

In 1982 recovery is predicted for export trade, both in coffee, and in exports other than coffee. Colombia expects to become an exporter of non-ferrous metals by mid1983, when the Cerromatoso project begins production of an estimated forty million pounds per year of ferr-nickel. In subsequent years, mining products such as coal should become an important component of the export mix.

A new pulp and printing paper mill will also begin operations next January in the Cauca Valley. Owned by Cartón de Colombia, its production capacity will be 50,000 metric tons/year of bleached pulp and 60,000 metric tons/ 
year of writing and printing papers. In Bogotá, Alcalis de Colombia is about to complete a new electrolytic caustic soda plant as well as the expansion of its iodine salt refining plant. Bogotá's automotive assembly production will also get a boost in late 1982, when GMC begins assembly of its Chevette and Citation cars, expected to take a large market share.

With current revenues off by 12 percent and current payments abroad up by 15 percent, Colombia emerged from 1981 with a deficit of some $\$ 645.7$ million, compared to a surplus of $\$ 735.3$ million registered in the previous year. In spite of this trade gap, the international reserves reached a record high of $\$ 5.6$ billion, a 4 percent increase over 1980. A good portion of the capital inflow related to private foreign financing was destined for the development of the El Cerrejón and Cerromatoso nickel mining projects. Colombia's energy profile has improved in the past year, not only due to the recent discovery of important oil fields in the Eastern Plains, but also because of the recent completion of the national electric power grid. The final link with the Caribbean coast power system gives Colombia added stability in a network that now expands all the major cities, the two coasts and the Venezuelan and Ecuadorean borders. Further stability comes from the 500 Mw Chivor hydroplant that went on stream in mid-December 1981, ending the need for electric power rationing. By the end of 1982, the $620 \mathrm{Mw}$ San Carlos hydroplant will offer 
back-up to the national power system, covering expected growth in demand through 1983.

Oil prospects again also look good. The Eastern Plains, mentioned before, are expected to become Colombia's most important oil region by the end of 1982. The yield by that date could be in the order of 100,000 barrels of crude oil per day, compared with the present daily rate of 3,500 barrels. This kind of production could once again make Colombia self-sufficient in its production of crude petroleum and might also provide an export surplus by 1985 .

The present rate of increase in Colombia's output of crude oil--6 percent per annum--outpaces the increase in domestic demand for liquid petroleum products. Contributing to this trend has been the secondary development of the upper Magdalena Valley oil structures, which have been yielidng 33,000 barrels/day. Consequently, imports of Iiquid petroleum actually experienced a 6 percent reduction from January-October 1981.

Rounding out the energy picture is coal mining, earmarked primarily for export. Coal mining will experience a surge in 1983-84 when the initial development of the Central zone of the El Cerrejón coal field is carried out, putting some 1.5 million metric tons per year on the international market. This will be followed in 1985 with a set up in production from the huge northern zone of El Cerrejón, targeted initially at some five million metric tons per year. This is a joint project of the Colombian mining company and 
the Exxon.

\section{Projections for 1982}

For 1982-83 a substantial recovery in Colombia's export trade is projected. Coffee is expected to register gains of 12 percent, based on anticipated increases in the price of coffee due to the most recent freezes in Brazil. Colombia's inventories are presently high and the country will again be able to act as a reliable source of coffee as a tighter supply-demand situation comes into play on the world market.

World economic improvements could contribute to a revival of Colombia's manufacturing sector, since industrial goods such as textiles, garments, cement and chemicals are produced in large part for foreign markets. Public investment and urban construction are expected to continue their trend of improvement in 1982 and 1983. The results in agriculture are also expected to be favorable, except perhaps in cotton, sugar and flowers which face possible drops in international prices.

Additionally, domestic mining is expected to contribute in the near future to a more stable balance of payments. By 1985 all liquid hydrocarbous presently imported, should be supplied from domestic sources. The continued flow of foreign capital, mainly for mining projects, should also help the balance of payments situation. 
Foreign Investment in Colombia

The favorable investment climate in Colombia has led to an increase in approvals of new foreign investment. According to different data, the National Planning Department granted approval for foreign investment projects amounting to $\$ 230$ million compared with $\$ 27.7$ million in 1978 and $\$ 26.6$ million in 1977. The step-up in foreign investment activity is linked to the strong economic performance of the past four years with GDP growth averaging eight percent per annum, and to the amendment of various regulations reflecting a more liberal attitude toward foreign investment within the guidelines of Andean Group agreements and standing Colombian Legislation.

Colombia has traditionally welcomed foreign investment, clearly establishing the rules under which the investment is accepted and providing fair and equal treatment. Among the priority sectors in which foreign investment is actively sought are: projects to increase production of export; activities which foster a further decentralization of manufacturing growth away from the three major urban centers of Bogotá, Medellín and Cali; and high risk ventures in the field of mining and energy development.

Enterprises in Colombia are divided into three categories in accordance with the degree of ownership of national investors. These are: 
- NATIONAL: Enterprises in which the national ownership of the equity capital is no less than 80 percent.

- MIXED: Enterprises having a national ownership of equity capital ranging between 80 and 51 percent.

- FOREIGN: Enterprises in which the nationaliy owned portion of the equity should not be less than 51 percent. Inspired by the basic common philosophy that foreign capital operating on a joint venture basis with national capital, promotes a more rapid transfer of know how and technology to local entrepreneurial groups.

Decision 24 of the Andean Group stipulates that manufacturing operations fully or predominantly owned by foreign investors cannot enjoy the benefit of the enlarged regional market. However, foreign enterprises willing to convert into mixed or national enterprises by selling part of their equity capital to Colombian investors may also enjoy these advantages as soon as an agreement is signed.

\author{
TABLE \#I \\ Direct Foreign Investment in Colombia \\ (Book value of Registered Foreign Capital Other Than \\ Petroleum and Natural Gas)
}

$$
\text { (U.S. \$ millions) }
$$

Agriculture

Mining

Manufacturing

Public Utilities

Construction

Hotels, Retail, Wholesale

and Restaurants
1978

7.6

30.1

572.6

.4

2.5

$85 . ?$

1979

$\underline{1980}$

11.1

53.6

48.2

648.9

2.6

749.8

.8
3.2

94.9

96.3 
Direct Foreign Investment in Colombia (Cont.)

\begin{tabular}{|c|c|c|c|}
\hline & 1978 & 1979 & 1980 \\
\hline $\begin{array}{l}\text { Transportation, Communs } \\
\text { Banking. Insurance, Rea }\end{array}$ & 29.1 & 30.3 & 32.1 \\
\hline $\begin{array}{l}\text { Estate } \\
\text { Communal, Social and }\end{array}$ & 112.8 & 119.1 & 110.2 \\
\hline $\begin{array}{l}\text { Personal Services } \\
\text { Non-specified activities }\end{array}$ & 2. & 2 & 2.8 \\
\hline TOTAL & $\$ 844.0$ & $\$ 957.4$ & $\$ 1,060.8$ \\
\hline
\end{tabular}

Source: Banco de Ia República

Tourism in Colombia

The number of foreign tourists annually visiting Colombia has risen to a level of 1.2 million (1980 figures) and in the last five years earnings increased seven fold from \$93.I million in 1975 to over $\$ 640$ million in 1980. The visitors are largely from neighboring Latin American countries, North America and Europe.

Coordinating the development of the tourist industry since 1968, the Colombian Government Tourist office (Corturismo) recently prepared a comprehensive national tourism plan focusing on a number of different regions. Corturismo's financial position was strengthened in 1979 by legislation empowering it to directly collect a special tax for tourism development.

Corturismo and the private sector have plans to expand the tourist industry through the construction of new modern hotels and convention centers. Within two years construction should be completed on four diversified con- 
vention facilities located in the cities of Bogotá, Medellín, Cali and in a small town called Paipa, which is northeast of Bogotá. These will be accompanied by improvements in the country's extensive air and highway services, and by training programs for management and staff of hotels, shops, restaurants, travel agencies and local transport concerns.

The past decade has seen a rapid rise in the number of tourists visiting Colombia from all over the world and particularly from neighboring Latin American countries. Almost three quarters of the foreign visitors came from two bordering countries: Ecuador ( 43 percent), and Venezuela (3I percent). Nine years ago these countries accounted for only about a quarter of the total number of tourists. From 1970 to 1979, the actual number of tourists increased twenty times, generating two-thirds of tourism earnings. In the same period, tourism from Europe tripled, and visitors from North America approximately doubled. From the rest of the world, mostly Central America, the Caribbean and other South American nations, the flow of tourists nearly doubled. Air arrivals and departures grew approximately 12 percent between 1976 and 1978, with close to two-thirds of the foreign air travelers arriving in Bogotá's EI Dorado International Airport. Airports in Colombia are owned and operated by a government corporation which finances improvements in landing facilities through an airport tax.

Colombia was a pioneer in commercial air service, the first to operate a regular commercial airline in the 
Western Hemisphere. Avianca, the leading airline, carries over seven million passengers annually, about ten percent of the volume corresponding to international passengers. While ocean arrivals account for only a small fraction of Colombia's tourist traffic, the number increased four and a half times between 1976 and 1978.

\section{TABLE \#2}

\section{Purpose of Travel to Colombia (1979)}

\section{Percentage}

Recreation

Business

Conventions

other reasons
41.3

3.0

23.1

Source: Colombian National Tourist Office

Colombia's strategic location on the northwest corner of South America makes it ideally suited for regional convention purposes. Colombia is now making a strong bid for Latin America's convention market. A total of four large modern convention complexes are to be completed by 1982 in Bogotá, Medellín, Cali and Paipa.

These new constructions will supplement Colombia's existing convention facilities in leading hotels such as the 800-room Tequendama-Inter-Continental and the Bogotá Hilton, now expanding to 800 rooms. In total Colombia has convention facilities in five major hotels, including three managed by Inter-Continental (Bogotá, Medellín and Cali), 
and two managed by Hilton International (Bogotá and Cartagena). With a present total of 1,500 rooms, these hotels have auditoriums and conference rooms of various flexible sizes, full restaurant services and ample recreational and social areas.

\section{Colombian Government Tourist Office}

Corturismo was organized in 1968 with the main purpose of promoting and financing the tourist industry. Towards these ends, it gives assistance to the construction of infrastmucture works required for tourism development, provides long term loans at moderate interest rates to Colombian and foreign investors for various tourism projects, and has frequently participated in the equity capital of corporations constructing modern hotels, particularly in the cities most likely to act as tourist poles. In more isolated areas believed to be of tourist potential, Corturismo has sometimes acted as a catalyst by building and managing in the early stages certain basic tourist accommodations.

"Corturismo has been given a sounder financial base through the passage of Law 20 of 1979 which empowers the agency to directly collect a tourist hotel tax. Estimates place the annual potential revenue of this tax at about \$10 milion in 1981, permitting completion of some vital projects as well as initiation of new investment programs for basic infrastructure works, primarily along the 
Caribbean coast."10 In addition, Corturismo oversees a substantial line of credit extended by PROEXPO who recognizes that the tourist industry has become a significant source of foreign exchange for Colombia.

\section{HOTEL INDUSTRY IN COLOMBIA}

Classification of hotels: one to five stars

Number of Establishments: 142

Number of Rooms: $\quad 11,056$

\section{TABLE \#3}

Supply of Rooms in Colombia by Departments

Number of

Establishments

Bogotá

Bolivar

Antioquia

Valle

Norte Santader

San Andrés

Magdalena

Atlántico

Tolima

Santander

Boyacá

Narin̂o

Cundinamarca
40

39

35

34

49

40

34

21

36

25

32

26

23
Number of Percentage Rooms of Rooms

2,951

2, 117

2,045

1,735

1,658

1,455

1,134

1,121

964

857

743

727

697
13.8

9.9

9.6

8.1

7.8

6.8

5.3

5.2

4.5

4.0

3.5

3.3

Note: Above figures include hotel rooms, motel rooms and apart-hotels.

Hotels in Colombia account for 27 percent of the lodging establishments, and 51 percent of the total rooms.

10 "Tourism in Colombia," Colombia Today Vol. 15, No. 2 (June 1980), p. 5. 
TABLE \#4

Type of Hotel

5 Star

4 Star

3 Star

2 Star

1 Star

TOTAL
Number of Rooms

$$
1,614
$$

1,327

2,609

2,996

2, 510

11,056

TABLE \#5

Type of Hotel

5 Star

4 Star

3 Star

2 Star

I Star

Bogotá

Antioquia

Valle

Magäalena
Number of Rooms

$1977-1978$

$1,514 \quad 1,614$

846

1,32 ?

2,231

2,609

2,065

2,996

2,455

2,510

\section{TABLE \#6}

Number of Rooms in

5.4 .3 Star Hotels

$$
1,662
$$

1,083

745

564
Percentage

14.6

12.0

23.6

27.1

22.7 $\frac{\text { Percentage of }}{\text { Variation }}$

$1977-1978$

$$
6.6
$$

56.8

17.0

45.0

2.2

Percentage

30.0

19.5

13.4

10.2 
The average number of beds per room in 1978 was 2.14. In terms of the number of guests per room it varies, depending upon the hotel classification:

- Five star hotel...... 1.3

- One star hotel....... 1.8

The biggest revenue center in hotels is the Rooms Department, with an average of 63 percent of Sales.

The northern part of Colombia, reveals a strong increase in the number of hotels. In 1977 for instance, there were 44 hotels, and in 1978 there were 51 hotels, an increase of 15 percent.

In Bogotá, the total number of rooms is 2,285 , which represents a 77.4 percent, showing that it is the region of the country which has the most qualified supply. 
CHA PTER III

THE DATA AND THE TREATMENT OF THE DATA

The Data

The data of this research are of two kinds: primary data and secondary data. The nature of each of these two types of data will be given briefly below.

The primary data. The responses obtained from the questionnaire and the personal interviews with the Operations and/or Finance representatives of the different International Hotel chains was the main source of primary data.

The secondary data. The published studies, texts, codes and reports, and the unpublished dissertations and theses dealing with either the basic requirements of the International Hotel chains when investing in Latin America, or dealing with the Colombian Laws and regulations concerning foreign investment are the types of secondary data.

The Criteria for the Admissibility of the Data

The responses from the questionnaire and the personal interviews and any other data that deal with the basic requirements of the International Hotel chains when investing in Latin America, was used in this study. The companies representatives which were interviewed were from: Hilton International, Inter-Continental, Holiday Inn, Sheraton, Hyatt International, and Marriott Corporation. 
Only the regulations and requirements that deal with foreign investment in Colombia were considered and used in this study.

The Research Methodology

The methods and procedures used in this study will be related to the descriptive survey method because the researcher will be gathering the data by means of personal interviews and by a questionnaire.

Specific Treatment of the Data for Each Subproblem

Subproblem one. The first subproblem was to determine the basic requirements of International Hotel chains when investing in Latin America.

\section{The Data Needed}

The data needed for the solving of subproblem one were the different basic requirements that the Intemational Hotel chains have and/or follow when investing in Latin America.

The Location of the Data

The data is located within each of the International Hotel chains studied, specifically in the Latin America division.

The Means of Obtaining the Data The data was obtained by means of mailed questionnaire 
and interviews using a tape recorder. The interviews were conducted at the headquarters of the hotel companies when possible, and its length varied depending upon the interviewee.

The Treatment of the Data and its Interpretation

The data was compiled and classified according to the requirements of the international hotel companies. Then, each individual hotel's basic requirements were analyzed. Once this was done, the researcher did summarize the most common and basic requirements of the international hoteI companies.

Subproblem two. The second subproblem was to determine if Colombia meets these basic requirements of the International Hotel chains.

The Data Needed

The data needed for the solving of subproblem two were the different laws and legal requirements that foreign investors have to follow when investing in Colombia.

\section{The Location of the Data}

The data was located in the law codes, law books and official Colombian documents that deal with foreign investment in Colombia. 
The Means of Obtaining the Data

The data was obtained by means of an intensive research in the different sources indicated above.

The Treatment of the Data and its Interpretation

The data was organized as follows: first the data that deals in general with foreign investment in Colombia, including the tax holidays, government incentives, the process that Multinational companies have to follow, remittance of profits and so forth.

Once the data was organized, the researcher did proceed to analyze and interpret it in order to find out if Colombian laws meet the basic requirements of the International Hotel chains or not. Based on this previous result, the researcher found out whether or not there was the probability of reaching an agreement between the Colombian Government and the International Hotel chains, in order for Colombia to attract more International Hotel chains, and hence, more foreign investment. 
CHAPTER IV

THE REQUIREMENTS OF THE INTERNATIONAL HOTEL CHAINS

THE SHERATON CORPORATION

INTRODUCTION

Sheraton was founded by two former World War I aviators and roaring twenties entrepreneurs; the two saw real estate investment opportunities during the Depression. From a meager beginning of a two hundred room hotel in Springfield, Massachusetts, the chain has grown into more than four hundred and twenty hotels, with approximately 110,000 rooms in 53 countries.

Rapid expansion of Sheraton was accomplished by buying up of existing hotels which exhibited an increase in the value of real estate. This was done by merging with a reality company. Sheraton, in the beginning, had ventured to take a path of expansion much different from the competitors. The founders emphasized that the company should own the hotels they operate and hence, the feeling among security analysts was that they were more in the tax business than in the hotel business.

The philosophy of the founders was that sheraton is a hotel chain, cum tax shelter, cum real estate investment trust. The founder of Sheraton felt, at that time, even if he breaks even in the business of muning hotels, he is 
still ahead by quite a few million in the real estate business of owning hotels.

As owner of vast amounts of hotel property, Sheraton had naturally combed the ins and outs of real estate tax from top to bottom. And by so naming Sheraton as much like a reality company as an operating hotel chain, most of the company's earnings were taken by the owners in the form of depreciation under the extra lavish real estate allowances offered by 1954 revenue laws. This allowed him and gave him cash to finance investments and improvements.

With real estate values declining, Sheraton revalued its assets and cut its net asset value by $12 \%$ or $\$ 74$ million. ${ }^{1}$ The expansion goals set by the company could not be achieved from internal financing or by borrowing money. The time had come to franchise hotels and operate hotels overseas under management contracts and thus follow the lead taken by other international hotel companies.

A multinational company was actively seeking companies which had growth patterns equal to or better than their own. It also looked at industries which were resistant to cyclical trends. This multinational company was attracted to Sheraton because it had an extremely good name, a name not limited to geographic area, and one which could be used around the world. So the stage was set, whereby

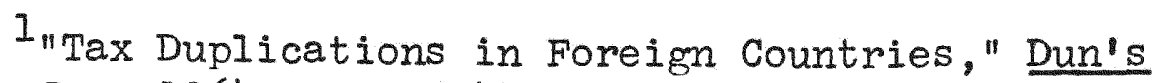
Review, June 1964, pp. 33-44. 
Sheraton could expand intemationally with the support and backing of this multinational company: ITT.

A. CRITERIA ESTABIISHED BY SHERATON PRIOR TO EXPANSION OVERSEAS

I. Primary Considerations

a) In the years 1945-1950, Sheraton aggressively sought investments opportunities overseas where the value of real estate would increase significantly. The founders of the corporation felt that real estate had been the first value to decline in the depression overseas, especially in Japan and Europe, and had dropped the furthest. Real estate values would also be the Iirst to come back in the recovery, they felt eventually had to cone. The first opportunity was in 1949, when two Canadian hotel chains were bought. ${ }^{2}$

b) Sheraton had been limited in its international expansion because of financial reasons due to both the opportunity for and availability of financing. Sheraton's past marketing penetration based on opportunistic criteria evaluating development sites and hotels offered but not selecting its own markets and sites. Overseas expansion outlimited needed a capital outlay of $\$ 365$

2 "Sheraton Corporation-Expansion Plans," Hospitality, December $1969, \mathrm{p} .68$. 
million. 3 These funds could not be raised by intermal financing or by taking loans out. Hence, the philosophy of the company was changed in 1970, whereby Sheraton became the manager of hotels rather than the owner.

c) Certain cities were initially selected because it was envisioned that there would be tremendous real estate values. Another important reason for the selection of certain areas was the fact that marketing studies had revealed the need of cities that are gateway cities, most of them with more than a million inhabitants, plus a projected or actual one million annual air passenger flow and projected increase in air traffic. So their strategy was to expand into prime tourist destination markets.

II. Tax Considerations

a) These played a major role in their decision to go overseas. For example, in 1969, there was a great need for hotel rooms in the city of London, and British Government was offering $\$ 1,000$ a room tax exemption for every new room built in Iondon. This was a primary consideration to build a hotel in Iondon and it was built by The Sheraton Corporation.

3"ITT Learns the Hotel Business," Business Week, November $3,1973, \mathrm{p} .55$. 
b) The initial feasibility study conducted by Sheraton looks at the tax structure very closely:

1 - Is there a double tax treaty between the foreign country and the U.S.?

2 - What are local regulations on "withholding tax" on foreign companies? What are the ramifications?

3 - Is there a foreign Tax Access Rate in the host country?

4 - Are these Deemed Taxes in a foreign country payable only on complete earnings?

5 - Is there a foreign tax credit so that the taxes that are paid overseas can be credited to the taxes paid in the United States?

III. Guarantee

In 1969, Sheraton had descended on a massive overseas expansion plan: "Our segment of expansion programs calls for addition of thirty new properties at a cost of $\$ 381$ million vs $\$ 81$ million put in by investors which Sheraton will manage," this was said by the President of the Sheraton Corporation.

Until this expansion plan was announced, they had not sought any kind of guarantee, nor did they back OPEC insurance. 
IV. Expansion Philosophy

a) Sheraton was aggressively expanding overseas because extensive studies conducted by their marketing department and by that of I.T.T., revealed that they had an extremely good name; a name not limited to any geographic sector, and one which could be used around the world.

b) A country is evaluated on the basis of whether it would be able to provide the market for the services they offer.

c) The corporate philosophy has been changed as far as building of hotels goes. From now on Sheraton will not own any hotels, but rather manage them. 4

B. CRITERIA USED FOR DEVELOPMENT OVERSEAS

I. Financial

a) Extensive studies are conducted by the marketing department of Sheraton, I.T.T. and more often than ever by an outsider (Accounting Firm), who conducts a feasibility study to determine the viability of hotel development in a foreign country.

b) Sheraton endeavors to follow the rules and regulations that are applicable in the host country. Being in a service industry, it has to be very careful, that it does not tarnish the public relations image. c) The decision to form a corporation, sub chapter

4"News from All Around the World," Sheraton World, Vol 6-No, 1, March 1974. 
corporation syndicate of any hybrid combination is dependent on location of the site. However, the form of organization already exists and could have an effect on the type of ownership or lease, the financing or the type of property which can be acquired or used.

In case of trust or a joint venture, the agreement spells out certain types of potential sites that are acceptable.

d) Feasibility studies dictate whether the project would be economically viable or not. After that a financial analysis is undertaken to determine:

1 - Gross Revenues

2 - Discounted Cash Flows

3 - Average Room Rates

e) An important consideration of the financial study is to determine how the expansion overseas will affect the financial structure of the parent company. Some financial considerations are:

1 - Return on assets

2 - Distribution of earnings

$3-\mathrm{P} / \mathrm{E}$ ratio

4 - Adequate coverage of fixed charges 


$$
\begin{aligned}
& 5 \text { - Profit margin on sales } \\
& 6 \text { - Return on fixed assets } \\
& 7 \text { - Return on net worth }
\end{aligned}
$$

II. Local Currency Loans

a) Dollar Loans

1 - Foreign financing of hotel projects is used for import of goods and services--this is perhaps the only source and is exclusively done by government owned credit institutions... Export-Import Bank. Sheraton makes their investment through the Export-Import Bank.

2 - Sheraton also involves the Agency for International Development (AID) who participates in numerous national development banks and has provided them credits which in theory may be loaned to hotel projects.

\section{Stability}

a) Sheraton is not looking at diversification as a means of strengthening their position in the hospitality industry, but they have entered another market, that of the "rest care center."

b) Their main purpose of expansion has been so that they could take advantage of mass marketing, merchandising and strengthen the referral system. But Sheraton Hotels and Inns will continue to 
stress quality in diversity. "Sheraton does not consider standardization of design as important as maintenance of high standards of services," says the President of the company, for standardization does not permit proper site selection, utilization and maximum exploitation of local characteristics.

c) Country social and political climate was not thoroughly examined until recently I.T.T. has an information file on rules and regulations for each country. So Sheraton has access to the files now, and is able to evaluate each country's social and political climate.

IV. Corporate Strategy

After the merger, I.T.T. had developed the demographics of the best customer, they came to the conclusion that the "best customer" is the average, middle management traveling executive. So their objective was to build moderately priced or lower priced hotels and hence, take advantage of a wide mariset range. I.T.T. until very recently dictated the philosophy of management that Sheraton ought to follow. That was to maximize and concentrate local autonomy at the daily operation level, but monitor 
progress at corporate level.

"Their philosophy is that reporting systems and central management techniques don't serve as restrictions to the line operator in the field, but serve instead as sources of strength and support." 5

Under the guidance of the new President, they embarked on a path where complete autonomy was given at local level, and this is the direction they are taking in all future developments.

Additionally, their growth plan is to maintain a $2 \%$ of the world lodging industry sales. And emphasis is being placed whereby they envision to increase to 3 or $4 \%$ of a much expanded market. This is perhaps a tough goal to achieve, as Sheraton is not the only company that is expanding.

C. CONTRACTS

I. Management Contracts

Company's philosophy was changed drastically from owning of hotels, to managing hotels and licensing agreements. Now it has been established that Sheraton will try to develop overseas properties under management contracts, under franchising agreements, ownership (few) and leases.

Management contracts afford the opportunity for the hotel company to expand rapidy. 
a) Important clauses in a management contract:

1 - Sheraton to act solely as an agent of the owner.

2 - Not to use Sheraton name in obtaining financing.

3 - Sheraton is not liable for any deficits ensuing from the operation of the hotel.

4 - The owner of the hotel to bear all operating expenses.

5 - A certain percentage of gross operating profit to be kept as a reserve for replacements, substitutions and additions to furniture and equipment.

6 - Title of hotel to remain with sheraton.

7 - Pre-opening expenses and services to be provided by the operator.

8 - Termination of services comes about when the hotel is not able to produce a profit. Sheraton being a very unique company, with a firm base it is financially strong as it is backed by I.T.T. money--so even when some hotels are money losers, they are sheltered and funds are provided by the parent company.

b) Compensation for a Management Contract

The management fee is calculated in the following way:

1 - A basic fee is charged, and that usually ranges from 4 to $5 \%$ of the gross revenue. This revenue covers the expense of the services provided, overhead expenses, marketing and reservation services, technical services, etc.

2 - Over and above there is an incentive fee which is approximately 8-10\% of gross operating profit. The purpose 
of this fee is to induce the management company to produce more and more profit and cut expenses and thus owner and operating company will both benefit from each other.

II. Franchise Contracts

a) Advantages:

1 - It requires no investment by franchisor.

2 - It is the easiest form of management; it is basically selling the name and providing marketing and reservation services.

3 - Reap profits based on occupancy.

4 - No liability if hotel is unprofitable.

5 - Signing a franchise agreement could be the only way possible to enter a particular country.

b) Sheraton provides a variety of services under a

franchise contract:

1 - A pre-opening manual and check list that help ease the difficult phase.

2 - Provide marketing sales and reservation services for a nominal fee.

3 - Sheraton design and development experts give advice and approval on architectural design, engineering, interior decorating and kitchen engineering.

4 - Sheraton assists in finding qualified key employees.

5 - Regional council concept has been established, which stresses creative planning. Key executives of each franchise hotel will meet with sheraton hotel leader four times annually in "think/idea" sessions. 


\section{LEASE ARRANGEMENTS}

I. Sheraton has made the preference for their expansion:

a) Management Contracts

b) Lease both Land and Building

c) Own Land and Lease Building

d) Franchise Contract

II. Sheraton has signed lease arrangements and has benefited under the two types of lease arrangements:

1 - Lease land and building; here the rent is deductible tax expense and would be true for both state and city taxes.

The disadvantage is that over years it may prove to be more expensive. At the end of the term, you have made payments of rentals but have no equity in property. It is important here and Sheraton has been shrewd to insist upon an option of renewal. However, Sheraton requires that a lease be capitalized as an asset on the leasee's accounting records and a balance sheet (at an amount equal to total lease payments discounted to present value over the term of the lease) then the lease is an economic reality. Sheraton has done this on two separate leases and benefited from this arrangement. --- Leases with a short initial term with a lease option to renew the lease for the remaining life of the property for substantially less than the fair rental value. 
2 - Lease land and construct building:

it is advantageous tax wise and also real estate taxes (as real estate taxes are considered as additional rent). This avoids freezing capital and eliminates commitment of funds.

Building is construction and can be written off or amortized over its useful life. At the end of the lease term, the building constructed by the leasee reverts into the hands of the leasor as the owner of the land.

E. RELATIONS WITH LOCAL GOVERNMENTS

This information was considered confidential by Sheraton and hence, they did not want to divulge it. 
INTER-CONTINENTAL CORPORATION

A. CRITERIA ESTABLISHED BY INTER-CONTINENTAL HOTELS CORPORATION PRIOR TO EXPANSION OVERSEAS

I. Primary Considerations for Going Overseas:

a) Inter-Continental Hotels was formed in 1946 as a wholly owned subsidiary of PAN AM, following discussions between the President of the U.S. Franklin D. Roosevelt and the President of Pan Am, Juan Trippe.

The main purpose of the formation of InterContinental Hotels was to build fine luxurious hotels that would attract businessmen to South America. Inter-Continental began operations by taking over management of existing hotels. Their first being in Belem, Brazil. Under the corporation original policy, hotels were to be situated along Pan Am's routes, and Belem was a stop on the airline flying north across the North Eastern shoulder of South America.

b) A feasibility study is conducted by two members of the corporation staff along with the division staff. They use the local

6"Planned. Growth at Intercontinental Hotels," Hospitality, February 1974, p. 50 . 


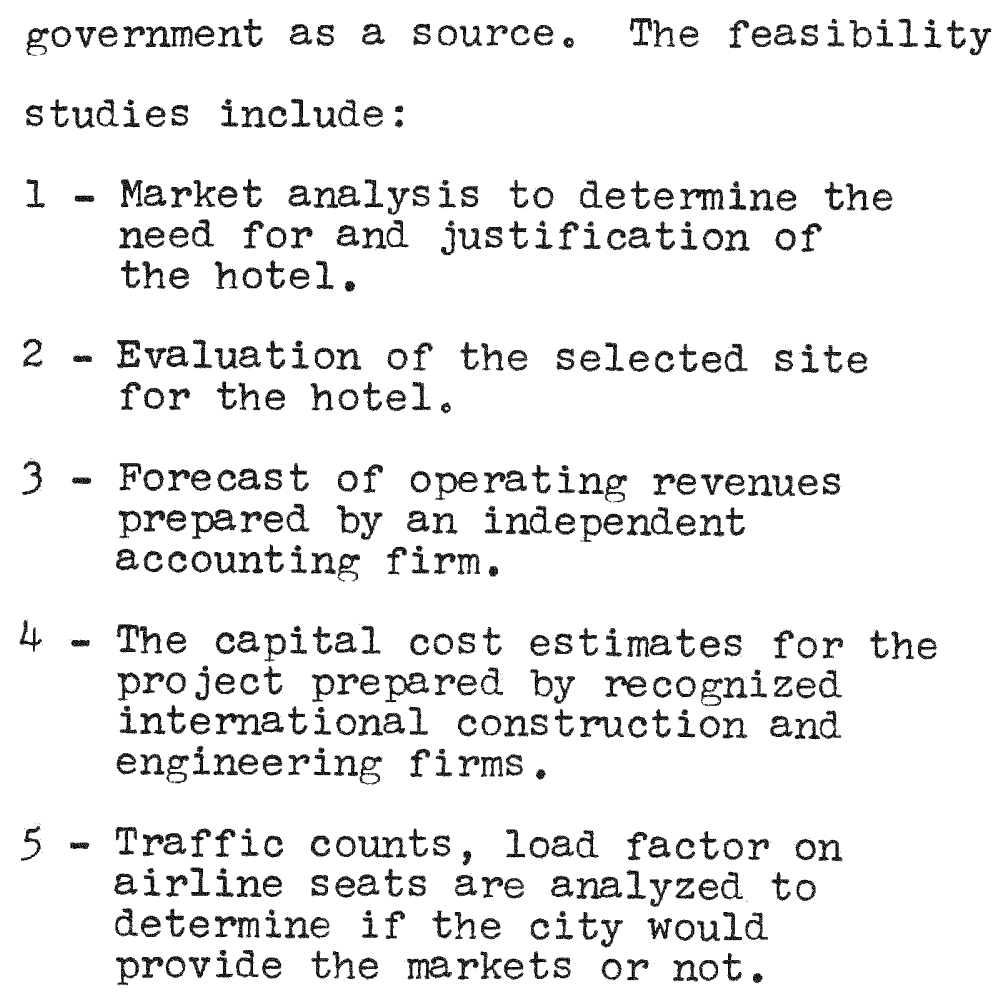

II. Tax Considerations

These play a minor role in their decision to build overseas. Generally the investment is made by the National Development Bank and is supported by local investors, so tax rebates and concessions basically affect the owners and not the operator of hotels.

III. Guarantee

Inter-Continental endeavors so that investment is funded locally or internationally, so often the need for guarantee does exist.

When some investment is backed or Inter-Continental puts a collateral on, then they buy "OPEC" insurance. This insurance is tied in with the federal government 
here in the U.S., so the company is fully protected. When the financing has been arranged through the Export-Import bank, then a suitable guarantee is sought from the host country.

IV. Expansion Philosophy

a) Inter-Continental Hotels Corporation was founded on the principal that hotels would be built overseas and along the ex-parent company's routes. Upon analysis, Inter-Continental found that there was a demand for luxury hotels in the areas where Pan Am did not fly. So from now on they will build hotels anywhere and everywhere there is a demand for a luxury hotel. They are expanding fast within the U.S.

b) Inter-Continental conducts a feasibility study of a general area, and this is done by a thirty-five page questionnaire which tries to determine the economic state of the country. Primarily the information sought also concerns the incentives offered by local government for the development for of company's hotels.

B. CRITERIA USED FOR DEVELOPMENT OVERSEAS

I. Financial

a) Inter-Continental believes that before a development of an international first class 
hotel is proceded, there is a great need to assure themselves of project profitability. Inter-Continental Hotels organizes comprehensive financial feasibility studies on behalf of potential investors. Inter-Continental views these studies as crucial to any commitment to and evaluation of a project by private investors, financial institutions or governments. Inter-Continental follows the following procedure in evaluating the profitability of the project:?

1 - The cost of capital of estimates for the project prepared by recognized international construction and engineering firms.

2 - Forecast of operating revenues prepared by an independent hotel accounting firm.

3 - A suggested plan for financing of the hotel, including suggested amounts, types and sources of all financing.

4 - A computerized twenty-year earnings and cash flow projection.

b) Inter-Continental prefers to form a subsidiary when it makes an investment in an overseas hotel development.

7World Bank Working Sector Paper on Tourism, 1972 Edition, p. 22. 
More often than ever, the type and form of organization is very much dependent of what country you are talking about. Different countries have different incentives for the type and form of organization an international hotel company may organize.

II. Local Loans vs Currency Loans

Inter-Continental prefers that the loans be funded locally or by any one of the following international financial institutions:

- Export-Import Bank

- Asian Development Bank

- Inter-American Development Bank

- African Development Bank

- The Bank for Central American Economic Integration

- The U.S. Agency for International Development

- European Investment Bank

- International Finance Corporation

III. Reasons for Seeking Loans Through International Financial Intermediaries:

a) It has been Inter-Continental's philosophy to emphasize the need for flexibility in considering the types of projects the international financial intermediaries may finance.

b) In many developing countries, there are reservations about the desirability of developing 
tourism on the basis of private ownership of hotels. So Inter-Continental tries to link such foreign ownership with interests in promoting and organizing the flow of visitors from the main market countries; hence, it can contribute significantly to the success of the project. 8

c) The international finance intermediaries might be able to promote various forms of joint ventures whereby the developing countries would retain majority ownership of the facilities while the foreign investors would have a large enough commitment to ensure their interest in the success of the venture.

d) Two features of the hotel investment in particular seem to account for the reluctance of local investors:

1 - The fact that relatively large amounts of capital have to be tied up in fixed assets over a long period $(22-25$ years) with all the risks of changes in market conditions, the political and social framework.

2 - The strongly seasonal demand which is particularly pronounced in resort areas. This gives rise to concern that it will not prove

8"International Hotel Development," Robert E. Smith, The Cornell Hotel and Restaurant Quarterly, February 1967 , 
feasible to achieve suffi-

ciently high occupancy rates

to make satisfactory profits.

IV. Stability

a) Rapid expansion overseas is undertaken for many reasons:

1 - To build and provide accommodations along Pan Am's routes was the main reason and basis of expansion. Nowadays, the expansion is dictated based on the results of the feasibility studies.

2 - To avail of opportunities that exist in prime tourist destinations that are developed or are developing.

b) Corporate philosophy is to minimize overhead expenses. Their objective is to draw upon local experts who would perform according to a set of guidelines and objectives set up by them. c) Inter-Continental is looking keenly at diversification and their objective is to increase their gross sales and ultimately increase profits.

Diversification is evident in recent moves made by Inter-Continental:

1 - They have developed economy hotels to take advantage of the wide demand for accommodations of the type.

2 - They are in the process of developing island inns (50-150 rooms) which would serve as destination resort areas of the future.

3 - They are producing and marketing worldwide educational materials for the hospitality/tourism industries. 
d) Inter-Continental wants to be represented in all areas of the world. The referral system is extremely good in the corporation. The interior design and development departments work extremely hard to give individual character to each hotel and relate the design and atmosphere of the countries where each is located. 9

e) Inter-Continental Hotels, endeavors to explore the social and political climate very extensively. The objective of their study is to determine what the social characteristics in a foreign country are that might restrict normal hotel operations, because these factors will very much influence the design of hotels. Secondly, Inter-Continental wants to guard very carefully the outward appearance and operation of the hotels and do not let them become a symbol of the political structure in the country. f) Both long term and short term growth, play a major role in the decision to expand into a country. But more emphasis is given to the country where there is the fastest possible return on investment.

V. Corporate Strategy

a) Inter-Continental's corporate strategy is to

9Richard Cromwell and Marilyn Greene, "Problems in Going International," The Cornell Hotel and Restaurant Quarterly, February 1967, p. 71. 
build luxurious properties in key metropolitan areas of the world. Secondly, they are building economy hotels to draw the economy minded travelers. Thirdly, they are developing an Island-Inn concept, to offer something different to the discriminating jet-set traveler.

b) As Inter-Continental develops, it is becoming more and more evident that the corporate staff located 100-1000 miles away is not aware of what is going on in distant countries. For this reason the company is decentralized and all operating decisions are made at division and local levels. 10 Division heads perform the function of setting policy, and standardizing the procedures for the country under consideration.

c) Inter-Continental works off a five year plan-this way they are able to establish what they need to do in sales volume.

Sales and marketing staff try to determine the reasons for "Marketing Shift"--what they should do to encompass this.

d) Inter-Continental has established criteria regarding the types of hotels they want to build,

10Robert E. Smith, op. cit., p. 65. 
and have placed them in the following categories:

1 - 50-150 rooms: Island Inns

2 - 250-300 rooms: Luxury Hotels

3 - 300-500 rooms: Economy Hotels

C. CONTRACTS

I. Management Contracts

There is not a standard management contract. Every contract has different characteristics and is negotiated separately and differently.

Management and technical fee percentages are most often based on Gross Operating Profit, and this percentage may be the same for all the hotels. $A$ basic fee is usually supplemented by an incentive fee payable if profits surpass a certain figure.

Services provide under the Management Contract includes such things as manuals of standard operating procedures for all areas of the hotel; Inter-Continental provides marketing and reservation services; the accounting staff of the hotel prepares the budget and sends it to the Area Financial Director who reports to the VP/Controller of the corporation. The contract will usually stipulate whether the notel company will provide technical services.

a) Liability of Management Contract: InterContinental is so structured that it operates through subsidiaries and local corporations, so 
that there is a limited liability in case of a financial difficulty. However, it is the company's policy to meet the commitments of its subsidiaries.

1 - In the event of losses.

2 - Provide capital needs to insure that the hotel does not go under.

3 - To reduce expenses to show a reasonable profit, Inter-Continental can defer their income (Management fee) until the property is financially sound and able to stand alone. 11

Inter-Continental Hotels ensures that repatriation of earnings is guaranteed by the local government.

b) Compensation for a Management Contract Management fee is calculated as follows:

1 - It is not based on gross operating revenue. It is based on gross operating profits. For example, it varies from $2-4 \%$ and they aggressively encourage the commission. With the recent expansion of other international hotel companies, and in an effort to maintain their market advantage, many times it more closely approximates the $2 \%$ figure. With this figure, the owners naturally make more profit, and hence, they write off depreciation and capital expenditures very rapidly.

II"Inter-Continental Hotels Excel in Hotel Design," Institution Magazine, Febmary 1968, p. 129. 


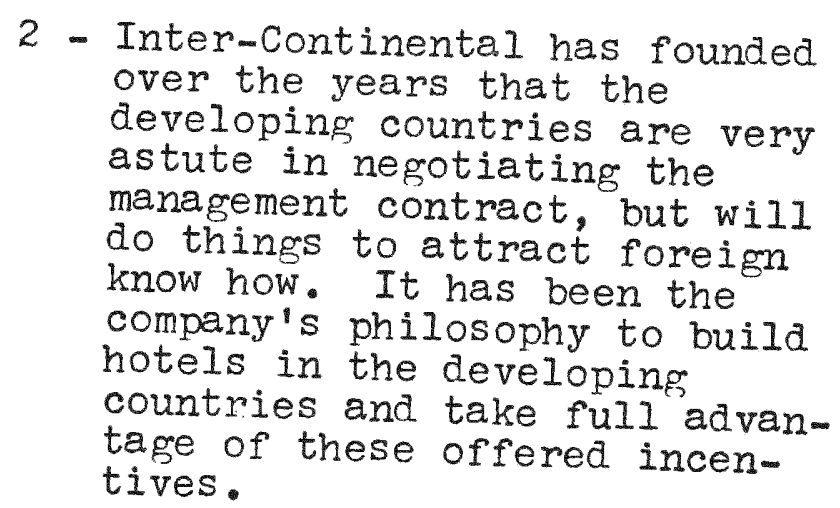

II. Franchise Contract

Disadvantages of a franchise contract:

a) Amount of profit is reduced vis a vis a Management Contract fee.

b) A franchise contract can be terminated at any time.

Overall, franchising is the best deal for Inter-Continental Hotels because it does not require any investment at all and financial benefit is substantial. An advantage of a franchise contract agreement is that it gives Inter-Continental an opportunity to develop hotels in areas where the local government has restrictions against hotels managed by foreigners.

c) Compensation: It is based on:

1 - Occupancy percentage

2 - Actual reservations made through Inter-Continental reservation 
d) Services under a Franchise Contract

1 - Marketing and reservation services are provided at a nominal cost.

2 - Standard operating procedures are provided at a minimum cost.

3 - Training and recruiting assistance is provided.

4 - Purchasing services are provided at a mark up price but generally are still cheaper than what the local hotel would pay.

5 - Audit services are included, with the right to audit the hotel. Inter-Continental's standards must be followed.

6 - A certified training program is provided for all job levels.

D. LEASE ARRANGEMENTS

Inter-Continental Hotels does not sign any lease arrangements with any of its overseas hotels.

E. RELATIONS WITH LOCAL GOVERNMENTS

A preliminary survey is done by Inter-Continental Hotels to determine what are the benefits and incentives given by the local governments towards hotel development. Some of these incentives given by some local govermments include: ${ }^{12}$

1 - Hotel Credits: Government credits for part or all of the loan capital (60-75\% of total costs) are made available under preferential

12Donald E. Lundberg, PH.D., "Caribbean Tourism Part II Social and Racial Tensions," The Cornell Hotel and Restaurant Quarterly, May 1974, p. 82 . 
rates of interest.

2 - Loan Guarantees: Is the government providing full financial guarantees without fee for domestic or international credits?

3 - Cash Grants: Some governments have adopted the policy of cash grants to hotel enterprises. This usually takes the form of a cash contribution towards building cost measured by the number of guest rooms and public facilities created.

4 - Share or stock underwriting.

5 - Decrease custom duties.

6 - Income Debentures: Government institutions can assist hotel financing by purchasing long term income debentures issued by hotel owning companies.

7 - Reduction of income and real estate taxes.

8 - Foreign exchange guarantees: as primary foreign exchange produces, hotels require assurances to obtain foreign exchange for payment of international operating costs, management fees, commissions, interest, dividends and salaries of foreign personnel.

9 - Immigration privileges for foreign personnel.

10 - Favorable public utilities charges.

11 - Advertising and sales promotion.

12 - Freedom from rent and price controls.

The more incentives of this sort that are offered, the better it is for the international hotel company to move into the country and establish a hotel. 
F. EXTENT OF RESTRICTIONS PLACED BY LOCAL GOVERNMENT AND HOW THE INTERNATIONAL COMPANIES DEAL WITH IT

1 - When regulations of any sort--currency, foreign exchange, labor, etc-are placed, Inter-Continental Hotels endeavor to negotiate with them.

2 - In several countries such as Saudi Arabia, Jamaica, only after the government has guaranteed the Ioan, does Inter-Continental develop hotels.

3 - When excessive currency regulations are placed on Inter-Continental, then a very minimal external investment is made in the project, to show that it is the corporation's belief that the project is a viable economic enterprise.

4 - Inter-Continental Hotels does not try to regulate its compensation. It is paid directly for the services provided-for example, franchised hotels buy technical services and pay directly for them. 
HYATT INTERNATIONAL

Hyatt International was founded in 1969, as a spin-off from Hyatt Corporation to develop hotels overseas. Hyatt Corporation has had an immense success in the regency type hotels (type of architecture, design and image that characterizes the Hyatt approach). A regency hotel above all is exciting. It moves, it flashes, it entices. Its unique architecture features a lobby care that rises to the building's full height. Hyatt Intemational is building regency type hotels overseas, and, they are an instant success wherever they are opened.

A. CRITERIA ESTABLISHED BY HYATT INTERNATIONAL PRIOR TO EXPAND OVERSEAS

I. Primary Considerations

Hyatt International, as it was previously mentioned, was formed in 1969 by Hyatt Corporation for the primary purpose of developing hotels overseas. Hyatt Corporation felt that there was a need for developing very fine luxury hotels in key metropolitan cities of the world, so as to provide the international traveler who is willing to pay top rates in every country. 13

Secondly, an important consideration for going overseas was the fact that hotel developments re-

13"A Hotel Chain Rises to Rival the Giants," Business Week, September 19, 1970, p. 101. 
quired little or no investment.

Thirdly, Hyatt Corporation was approached by local investors who came to them and made proposals for hotel development. Hyatt International was soon formed thereafter, and its representatives now keep its corporate office informed of the potential cities for development of hotels.

II. Tax Considerations

Since Hyatt International is not an investor, tax rebates and reliefs do not affect them directly, and hence, are not important considerations. On the other hand, if a favorable tax stmucture exists, it surely helps and plays an important role in their decision to build in that country. If the tax structure is favorable, then it is a tremendous help to the local investor, as he would easily be in a position to pay his tax liability and hence, Hyatt Corporation is pretty well assured of its management fees.

Hyatt Intemational does not pay or provide for federal income taxes as earnings of their foreign subsidiaries is intended to be permanently reinvested. This is advantageous to the International hotel company because the tax liability in terms of percentage of net income is much less than the corporation's tax liability. 
III. Guarantees

Hyatt International's philosophy is that they will make very minimal or no investment overseas so they do not find the necessity of guaranteeing the minimal investment.

B. FINANCIAL ASPECTS

I. Hyatt International does not take extensive analysis on the long mun economic possibilities of a country. This is mostly because Hyatt joined the international hotel development at a rather large stage, and usually manages hotels wherever short run opportunities exist.

However, a proposed hotel development undergoes a thorough evaluation to determine whether the project is viable or not. This is done by pro-form studies conducted by in-house accounting specialists. 14

The decision to form a subsidiary, branch operation, joint venture, etc., depends on local statutes and codes. In order to maintain a good relationship in a foreign country, Hyatt endeavors to follow mies and regulations closely.

The type of arrangement with the local investors will also be dependent on constraints on type of financing arranged and these conversely are dependent on tax considerations and legal requirements.

Hyatt International firmly believes in following 
the principle of being flexible. For example, no rigid rules are established as regards to type of business arrangements. Their objective is to remain flexible enough to operate a hotel, regardless of what the local conditions dictate. This is perhaps the most important reason of deciding Hyatt's rapid expansion. Specialists in financial management within Hyatt Intemational calculate the profit potential of a new hotel venture. To assist a new hotel in meeting its debt payment, Hyatt signs a "stand aside agreement"--whereby management fee payments to Hyatt International are deferred and paid at a later date. In this way the new hotel venture is able to meet its debt service loan payment and as a result the profitability of the proposed hotel venture is reassured. 15

II. Local Loans vis a vis Dollar Loans

Hyatt's corporate philosophy has been to make no investment in overseas hotel developments. Financial officers of the company who are conversant with the international financial intermediaries guide local investors in seeking funds.

Investments are minimal so the question of raising money does not arise. In certain countries, where exchange regulations exist to overcome these restrictions, Hyatt International may be forced to reinvest part of the funds. Only under these conditions does

15"The Private World of Pritzkers," New York Times, october 14, 1973. 
Hyatt International require that a foreign country guarantee the investment. It may be prudent to mention that if a proposed hotel development looks exceptionally good, then Hyatt puts up the working capital and provides for the pre-opening expenses of the proposed hotel. But Hyatt is smart enough to sign an agreement with the investors of the hotel that they will get their investment back as soon as the hotel is operating financially sound.

\section{Stability}

Rapid expansion has primarily been due to demand for hotels in developing and developed countries of the world. With the increase in the number of hotels has led to consistent increase in revenues. This justifies the increase in marketing and merchandising programs and strengthening of technical assistance services. As the competition between the luxury hotels is on the increase, the overhead and corporate expenses will tend to increase proportionally. The purpose of this is to strengthen the referral system and other services provided under a management contract.

Hyatt International has no specific plans for diversification because they feel there is still a tremendous untapped market.

The significant growth of Hyatt Intemational can be directly attributed to high quality accommodations, 
catering to the public's demand for exciting "fun" places to stay, that they have built around the world.

Hyatt does very little to find out about the social and political situation in a country. 16 The consequences of this could be harmful for the long range tourist development in a country. Many reasons for the dissent are due to some of the following reasons:

a) The culture clash.

b) Rapid change in the life styles of natives-this brings uncertainty and resentment as people adjust to these changes.

c) Social and communal pressure resist innovation.17 Hyatt of course is looking at long term growth in the city or the area they want to expand. The primary consideration for expanding in an area is that the market for the services they produce already exist, as it is not entirely dependent on the international traveler.

IV. Corporate Strategy

Hyatt's strategy from the very beginning has been to build exciting new hotels in the metropolitan areas of the world. Added to this is the company'd dedication

16"A Hotel Chain Rises to Rival the Giants," Business Week, September 19, 1970, p. 101.

17 "Top Hotels in Every Country," Institutions/Volume Feeding, September 1971, p. 55. 
to the belief that service to the guest demands excellence and innovation in architecture, cuisine, interior design and marketing. They firmly believe that every luxury hotel should fulfill a guest's ideals.

Another strategy of theirs is not to build moderately priced hotels. The reason behind it is that cost of construction is going up, it would not be a good idea to reduce the quality of first class accommodation as the intemational traveler expects it. Also, they will not be saving that much and hence, may lose their market: the affluent traveler.

Hyatt International's strategy is to stress dramatic and spectacular architecture in their hotels. Hyatt is very decentralized with all the decisions made at the regional level or by the general manager. In this manner, a lot of autonomy is given to the manager at lower levels too.

Hyatt's growth in the past $5-7$ years has been astonishing and they expect to double its total volume in three years--an achievement that would add to an already impressive growth.

\section{MANAGEMENT CONTRACTS}

Management contracts differ from property to property. A substantial amount of inflexibility has been built into the type of contract Hyatt International signs 
all over the world. Hyatt arrived late to the international scene, so it has relinquished some of the rights held by other international hotel companies, in order to compete aggressively in the market place.

Hyatt has not developed standard operating procedures for all areas of the hotel. Much of this is the responsibility of the regional manager. The standard operating procedures in existence have a lot of flexibility built into them. Operating budgets are prepared by the comptroller of the hotel and are sent to the corporate office for approval. An operations analyst working with a budget analyst tries to determine if the budget presented is accurate. Local economic indicators plus past performance of the hotel are kept in perspective when evaluating the budget of the hotel. The local hotel management has authority to disburse funds, keeping in mind the guidelines established by the corporate office.

Hyatt does not seem too concerned with the liabilities ensuring from the hotel operations overseas and hence, decided there was no need of taking any insurance to protect themselves. This policy might change very soon because the international market is turning more unpredictable day after day.

If the owner of a hotel cannot perform his obligations, then the question of termination arises. On the other hand, some of the management contracts are signed on performance basis. So if a management firm cannot 
achieve results over a period of time, then they are removed from the scene and another hotel company will be brought in.

I. Compensation for a Management Contract Hyatt prefers an arrangement where compensation is based on performance. These are written for 30 to 40 years with 25 years additional options. Hyatt's fee is based on percentage of sales as against a percentage of gross operating profit. The purpose of this arrangement is that there is less financial exposure for Hyatt. Their feeling was that until something better is devised, it is the way most future contracts will be written.

Hyatt does not require overseas hotels to use the services of its supply companies. Hyatt does charge a consulting fee if the construction of the hotel they will be managing is poorly done, because they will make changes in architectural style to make it operationally smooth. For example, they may sometimes have to change grade plans to improve the operating efficiency of the hotel.

\section{FRANCH IS ING AND LEASE ARRANGEMENT}

Hyatt International will not sign any franchise or lease contracts because they like to have a $100 \%$ control of the management of the property. 
E. RELATIONS WITH LOCAL GOVERNMENT

Hyatt International does not have any major investment in any of its overseas properties. They get a fixed fee and seek guarantees from the government of the country in which they operate. They ask for the following:

a) Be allowed to repatriate their eamings.

b) Foreign personnel employed by the hotel be allowed to repatriate their salary. 


\section{HOLIDAY INN CORPORATION}

\section{A. CRITERIA ESTABLISHED BY HOLIDAY INN PRIOR TO EXPANSION OVERSEAS}

Holiday Inn realizes too, that Central and South America are the places to invest, to look for growth. This area has a tremendous potential for tourism, that is why Holiday Inn is so anxious to get into this area in which, at one point in time, they had 70 projects in South America out of which only 8 came out.

Holiday Inn's policy specifically for Latin America is to have either a Management Contract or a Joint Venture. Holiday Inn does not want franchising, because they are afraid of dealing with a local investor who does not know too much about managing a hotel and then hurting the company's image and standards. If there is an opportunity in Latin America they want to manage that operation.

Holiday Inn does not want to own any properties in Latin America, at least for now, because Latin America is a new market for Holiday Inn, and one which they do not know quite well.

Part of Holiday Inn's policy is that once they enter into a country, they will spread out to other major cities. The company of course will first come to the capital to develop a reputation, and an image; in short, to establish a corporate identity. 
The first step in considering any project is of course a feasibility study, which is always done by a third party, (Laventhol and Horwarth, for instance). Neither Holiday Inn, nor the investor do the study, for obvious reasons especially for the investor.

Holiday Inn looks for sites where commerce is located as well as the airports. It is their opinion that for most of this region, the business market is the dominant one, and the one Holiday Inn wants to enter.

B. FINANCIAL ASPECTS

In terms of the financial considerations:

1 - Holiday Inn's investment in Latin America is restricted to the furniture and fixtures. In order for them to invest, they must first see the property built and count with Holiday Inn's Engineering Department's approval.

2 - Equity participation from Holiday Inn depends on the situation and who the investors are. Holiday Inn demands to know, who is doing the financing and if it is done well; if not, they will not get involved if financing is not sound.

3 - Holiday Inn looks for projects with a good return and hopefully a low risk. In this matter, it was very interesting to find out that Holiday Inn views Colombia as a country which cannot be considered a "bad risk." Colombia is an acceptable country to invest.

4 - Holiday Inn works with various U.S. banks to help the investors get the financing. The company brings together the bank and the investors to make all the necessary arrangements for the financing. (This is done for Joint 
Venture or Managements Contracts agreements). Today, because of the economic situation, this is not being done, which is hurting Holiday Inn as well as the countries and cities where projects had to be stopped because of the lack of cash.

C. RELATIONS WITH LOCAL GOVERNMENTS

In order to avoid any problems between Holiday Inn and the local governments, the company has a policy which is to try to have natives of that particular country working in the hotel. This is in order to avoid any complaints in terms of discriminations against the local people and their management abilities.

Holiday Inn does evaluate the local conditions of the countries where they want to have projects. The social and political climate is evaluated by the lawyers and specific people who are at the headquarters in Memphis, Tennessee.

Holiday Inn wants, of course, to have the best relationships with the local governments for the company's benefit and the government's as well. 
HILTON INTERNATIONAL CORPORATION

A. CRITERIA ESTABLISHED BY HILTON INTERNATIONAL PRIOR TO EXPANSION OVERSEAS

I. Primary Considerations

a) Overseas developments generally do not require any investment, and this is in keeping with the corporate strategy of managing hotels rather than owning them.

b) Hilton International would not consider a project on any city, if the city cannot justify a new hotel. The secret of a successful hotel is only to build it if the town needs it, not otherwise, since every investment in each one of these properties must have a fair return to the investors. c) A feasibility study, which includes a marketing and an economic study is also done. This feasibility study includes:

1 - Evaluation of the selected site for the hotel.

2 - Forecast of operating revenues prepared by an independent accounting firm ( $I$ \& $H$, Laventhol \& Horwarth).

3 - Traffic counts, load factor on airline seats are analyzed to determine if the city would provide the markets or not. 
II. Tax Considerations

In considering a new project, obviously it is extremely important what tax concessions are granted by the government not only for the importation of items related to the construction and equipment of the hotel, which might not be available in that particular country, but also tax concessions in the operation of the hotel, as well as on the investment.

The time to obtain these concessions is when the project is under study, since being a hotel is a good source of new jobs as well as a producer of hard currency, it is easy to get the government excited about it. Also if the city does not have decent hotels, the building of a new hotel is a matter of prestige for the government.

\section{B. FINANCIAL ASPECTS}

For Hilton International the financing aspect of a project is of extreme importance:

I - It is of primary importance to know the origin of the capital to be invested.

2 - Another important factor is the possible source of financing. For your information, Hilton International recently refused a hotel project in Montevideo, Uruguay, since the capital to be used was coming from a not so clear source.

3 - Since hotels require a very large investment and the return is on a long-term bas is which might not be of interest to 


$$
\begin{aligned}
& \text { some of the prospects, in } \\
& \text { many cases, in order to } \\
& \text { stimulate the creation of a } \\
& \text { new hotel, the government } \\
& \text { takes an active participa- } \\
& \text { tion by either investing in } \\
& \text { part of the capital required, } \\
& \text { or the entire capital }
\end{aligned}
$$

In some instances, Hilton has been able to buy suitable land from the government by paying them with stocks in the new company. For your information, close to half of the hotels that Hilton International operates are owned by the government, or partly owned by the government with local capital also taking participation. In Bogotá, Colombia, the Colombian Police is the owner of the Bogota Hilton; hence, the Colombian Government.

\section{CORPORATE STRATEGY}

It is Hilton International's general policy not to invest in hotel projects. If they were to do so, instead of managing 90 hotels, they would probably own 10 or 12 .

One of the advantages of doing business with a company like Hilton International, is that they have a worldwide organization, with an extensive marketing organization, and plenty of know-how and experience.

Hilton likes its hotels to become the center of the community, and they are designed with this purpose in mind. Their function is not only to accommodate the out of town visitors, but to serve the community where they are located. For this reason, Hilton is very 
careful in the planning of the different facilities the hotel must have.

Another aspect of Hilton's corporate strategy is to build and/or manage quality properties all over the world, where existing markets are or will be in the future. An important factor in Hilton's expansion is their consideration of Central and South America as the market with the greatest potential for growth.

D. MANAGENENT CONTRACT

The Hilton International management contract includes a contract for technical assistance during the construction of the hotel. Hilton's charge for this service is based on their experience of what would strictly cost them, since they do not make any profit on it. Hilton has an extensive technical department in New York available for this purpose.

The standard management contract calls for the paye ment to Hilton of a basic fee of $5 \%$ of the sales and an incentive fee of $10 \%$ of gross operating profit. Hilton has found that this is a formula that pays them a fair fee and gives the owners a satisfying return.

E. RELATIONS WITH LOCAL GOVERNMENTS

A preliminary survey is done by Hilton International to determine what are the benefits and incentives given by the local governments towards hotel develop- 
ment. This preliminary survey is included in the feasibility study. 


\section{MARRIOTT CORPORATION}

Marriott Corporation founded in 1927, starting with a six-seat beer stand. Today it is an acknowledged leader in the food/service/lodging/leisure time industry. Marriott Hotels felt that their expansion in the U.S. was Iimited to forty major cities and twenty smaller cities. They needed to expand their name internationally; therefore, are seeking hotel developments overseas.

A. CRITERIA ESTABLISHED BY MARRIOTT CORPORATION PRIOR TO EXPANSION OVERSEAS

I. Primary Considerations

Marriott decided to expand overseas for the following reasons:

a) Overseas developments generally do not require any investment, and this is in keeping with corporate strategy of managing hotels rather than owning them.

b) The hotel business overseas is very Iucrative and by taking a management fee, the operations can expand at a faster pace.

c) There are only thrity-five major cities in the U.S. Where major Marriott Hotels can be built in 500-1000 room units with extensive banquet and recreation facilities. There are another twenty cities where 200-300 room hotels can be built. 
So in order for Marriott to reach masses of population and get a piece of the international market, it was and still is, felt necessary that Marriott go overseas.

d) Another important reason for going overseas was that the hotel expansion would tie in with other lines of business operated by the company in the international markets.

Since the corporation operates cruise ships, expansion of hotels acts as a support for this venture.

II. Site and Area Selection

The same criteria is used for site selection as is used in the U.S. The site and area selection are dependent on:
a - Labor availability
b - Ability of investors to finance the property
c - Tourist attraction
d - Historic value
e - Business activity attracting national or international business
f - Strength of primary markets, group, transient or tourist.
g - Pro-forma operating projections.

III. Tax Considerations

a) These play an important role in the decision 
to build in a foreign country. For example, a big incentive that encouraged Marriott to build a hotel in Barbados was the lack of an import tax on furniture, fixtures, and other equipment that had to be imported. This equipment was not available in Barbados, consequently, substantial savings were realized in total project cost.

In addition to the above benefits, there are tax rebates offered during the first ten years of operation.

b) Similar types of incentives are also available in other islands of the Caribbean, mainly because the local governments are actively soliciting U.S. technology in the hotel industry. This was one of the reasons why Marriott began programs of condominium development of Puerto Rico.

c) The development of hotels is primarily associated with and dependent upon the ability of the project to provide a tax shelter for the investors. This is done because stock analysts are looking at $P / E$ ratios above anything else. They are looking not necessarily at how many buildings they can own, but rather are encouraging the hotel companies to diversify their portfolio via management contracts and 
thereby offer tax incentives to businessmen who are earning more than $\$ 200,000$ annually.

d) An evaluation is made to determine the amount of taxes they would pay overseas as opposed to those paid in the U.S. If these taxes are much greater than those paid in the U.S., then going overseas would not prove financially sound.

IV. Guarantees

Marriott feels that even when the investment is guaranteed, there is always a risk; there is no situation where you get a 100\% guarantee.

But overall, it is a consideration, and Marriott at all times wants to minimize the risk and also do away with the possibility of having a continuing Ioss.

To protect their interest in a foreign country, they buy OPEC Insurance which is underwritten by the U.S. Government.

If Marriott feels that there are excessive restrictions, then they are reluctant to go into the country.

However, insurance is expensive. Whenever the risk increases, insurance rates go up. So insurance isn't always the answer. Marriott will not guarantee the payment of loans borrowed from international financial intermediaries. However, they may not 
take out certain percentage of management fees, so there is enough gross operating profits to pay the debt service capital.

Insurance will be made according to the investment and potential earnings and is directly related to the risk of the country. Normal insurance is still purchased to take care of the liability ensuing if, for example, a guest falls.

\section{B. FINANCIAL ASPECTS}

I. An initial study is undertaken to determine the following:

a) Current versus future needs of the hotel.

b) Projected gross revenues and hence determinations of the average room rate.

c) Optimum debt-equity ratio.

d) Cost projections.

e) Cost of equity in order to give advice to investors.

f) Evaluation of owner's financial background is made, to determine the financial stability of the investors.

g) Type of financing needed.

h) Projected cash flow analysts.

i) Amount of funds needed for working capital and pre-opening services.

j) As no two deals are alike, especially when 
the interest rates, currency fluctuations widely affect the investment decision. For instance, not too many foreign countries have the cash available; thus, money comes out of a commercial bank in the U.S. The commercial bank lends the funds because the local government will back the money. Even then, a certain amount of risk and gambling is involved. k) Pro forma studies are conducted to determine the effect on the hotel under $80-70-60 \%$ occupancy levels and this is done because world economic conditions keep changing. This affects considerably the occupancy of international hotels.

1 - Are the local investors capable of coming up with the investment needed to construct the hotel? Marriott tries to make a requisite whereby debt-equity ratio is in the $30-70 \%$ bracket.

II. Local Currency Loans vs Dollar Loans

Marriott recommends that the investors are better off getting local loans, because all the earmings are in local currency; hence, currency fluctuations will not affect interest payment for foreign loans adversely. 18

18 Richard Cromwell and Marily Greene, "Problems in Going International," The Cornell Hotel and Restaurant Quarterly, February $1969, \frac{p}{p} 87$. 
Usually many U.S. banks have money in some of the foreign countries in which they are doing business and have funds available and provide loans for the construction cost and so forth. Sometimes financing is arranged through the World Bank or the Export-Import Bank. This gives an umbrella of protection for the other banks to come in under and invest.

\section{Stability}

Marriott's expansion philosophy has been to build hotels in a given general area so as to cut overhead and corporate expenses. Their expansion philosophy is:

a) To take advantage of opportunities that exist in the international market.

b) Marriott diversified into airline catering, restaurants, and theme parks with the main purpose of taking benefits arising out of the markets that existed. The biggest caterer in Northern Europe was bought out to strengthen the airline catering business. Marriott is strengthening its base by entering into condominium development.

c) The philosophy of the company has been changed and the emphas is now is on "leisure type business," which they called "away from home market." 
IV. Corporate Stratery

Firstly, the corporate strategy is to build quality properties all over the world, where existing markets are or will be in the future. Marriott will not build moderately priced hotels and take advantage of accommodation needs of the masses.

Secondly, the proposed hotel is only built when it is established that the hotel will be able to stand on its own two feet in that it will achieve $80 \%$ occupancy. If the proposed hotel cannot achieve that, then either the project is rejected or delayed.

The growth rate is established in order to achieve a $100 \%$ growth in five years, and double the sales every five years.

Long run growth is considered to be twenty years. This is because when foreign source capital is brought in, the banks want the same period of time to amortize the loan, while the International Hotel company will have the management contract. However, the problem here is to know what the political situation will be in the area. For example, the current situation in Central America, and how it would affect business and its consequences. In a situation such as the one just mentioned, Marriott endeavors to get a little higher management fee over a six year period and only then is the project economically sound and viable. 
C. CONTRACTS

a) Management Contracts

Services provided under management contracts:

1 - Design and development

2 - Technical assistance

3 - Managing and equipping the property

4 - Standard operating procedures for the hotel

5 - Preventive maintenance systems

6 - Sales and marketing services

7 - Budgeting and accounting procedures

8 - Services of Marriott's supply companies are not made mandatory

9 - Food and Beverage systems are established. Then if the hotel has a problem in a certain area, a team of experts is sent in to solve the problem.

Manuals are provided for all areas, but certain areas may be changed a little bit, for instance, as far as serving food. But the same standards of food would apply in Boston as in Rio de Janeiro. Marriott endeavors to maintain standards of hygene and sanitation all over the world.

b) Compensation for a Management Contract:

Marriott charges $6 \%$ of gross sales to cover cost of:

1 - The national sales office

2 - A regional team

3 - Part of corporate expense 
c) Franchise Contracts

Marriott has changed its corporate philosophy and will not franchise anymore.

The reasons are:

1 - They lose management control of the property, and hence, sometimes the franchise compromises the quality.

2 - Customers do not know if the property is franchised or not. Consequently, Marriott has decided that it is not worthwhile to put the company's name on something they cannot control.

3 - By franchising, they sacrifice the long term benefits they would. derive by operating the hotel themselves.

D. LEASE ARRANGEMENTS

Marriott considers leases to be very risky, so they do not get into that type of arrangement. Another reason for this refusal, is that in a lease the company is bound (financially or otherwise), because then, they have long-term fixed payments. The obligation is the same as of an owner; therefore, the risk is increased manifoldy and is not worth pursuing any project under these conditions.

E. RELATIONS WITH LOCAL GOVERNMENTS

An analysis is done on the local government to try to determine the following aspects:

1 - What are the incentives offered to a local investor developing a hotel property? 
2 - What is the government's attitude towards the business climate?

3 - Try to get an inference of government's attitudes who has laid down restrictions after a foreign operated hotel has been in operation.

4 - Whether pay back method vis a vis net present value or internal rate of return will be most beneficial in a certain country.

5 - Sometimes a hotel development is supported by a local government, which may not be too concemed with financial returns because the project is to initiate tourism development in the country.

6 - What are the restrictions laid down by the local government in terms of the amount of equity that can be invested by foreign sources?

7 - The extent of the government's involvement in the project will determine the amount of investment Marriott will make in the project. The risk is then reduced substantially, and a different evaluation will be made. The banks lending money after knowledge of the government's involvement may make longterm loans at a much lower interest rate. 
CHAPTER V

FOREIGN INVESTMENT IN COLOMBIA

\section{A. DEFINITIONS}

- Direct Foreign Investment: Is defined as the contributions from abroad, belonging to foreign individuals or juristic persons, made to the capital of an enterprise in freely convertible currencies or in physical or tangible assets, whose owners shall have the right to re-export their value and to transfer their profits abroad.

- Enterprise: In applying the mies on foreign investment, the National Planning Department acts on definition of enterprise as given under Article 25 of the Colombian Commercial Code, which reads as follows: "An enterprise shall be understood to mean any economic activity organized for the production, transformation, circulation, administration or custody of goods or for the rendering of services. Such activity shall be carried out through one or more business establishments."

I Departamento Nacional de Planeación, Foreign Investment in Colombia: Basic Rules. (Editorial Presencia, 
- Foreign Enterprise: An enterprise formed or incorporated in the receiving country, whose capital held by national investors is less than $51 \%$ or, if more than that, where such percentage is not reflected in the technical, financial,. administrative and commercial management of the enterprise, at the discretion of the competent national agency.

- New Investment: Any investment in new or existing enterprises made after JuIy 1, 1971.

- Reinvestment: The investment of all or part of the undistributed profits of a direct foreign investment in the same enterprise where such profits were generated.

B. GUIDELINES FOR THE AUTHORIZATION, REGISTRATION AND CONTROL OF FOREIGN INVESTMENTS

Every foreign investment application shall contain:

1 - Description of the investor:
a) Full name
b) Nationality
c) Composition of Board of Directors
d) Composition of Staff and Management
e) Economic Activity
f) Copy of Articles of Incorporation

2 - Form of Investment:

a) Financial resources in currency or credit:

- Currency in which the investment will be made 
- Capital of national origin

- Capital of foreign origin

- Credit from parent company

- Credit from other sources

- Effective interest payable on credits

b) Physical or tangible resources, such as:

- Industrial plant

- New and reconditioned machinery

- New and reconditioned equipment

- Spare parts

- Parts and pieces

- Raw materials

- Unfinished products

c) Resources arising from technology or intangibles such as:

- Trade marks

- Industrial models

- Management skills

- Patented or unpatented know-how

- Possible alternative technologies

3 - Requirements being met:

a) Short supply of domestic savings

b) Short supply of foreign currency

c) Lack of management or administrative skills

d) Need for access to technological know-how

e) Lack of local entrepreneurial spirit

4 - Plan for progressive national participation:

a) Percentage of stock to be placed with national investors

b) Period of time and terms for implementing it

c) Method to determine the value of each allocation

5 - Effects of the new investment:

a) Approximate date of commencement of normal operations

b) Operating capacity

c) Exportable production

d) New employment

e) Imports of raw materials or unfinished products, in annual production 
f) Utilization of local unit

General Criteria

The National Council for Economic Policy shall determine the criteria to be applied by the National Planning Department in studying the applications for foreign capital investments or substitution of investments, for which purpose it shall take into account:

a) The contribution of the investment to the country's level of employment;

b) Net effect of the investment on the balance of payments;

c) Degree of initial and subsequent utilization of national raw materials and of parts or components now manufactured or to be manufactured henceforth in Colombia;

d) Proportion between the imported capital and the requirements of the respective enterprise for fixed investment and working funds;

e) Participation of national capital and investors:

f) Degree of competition of the line of products in question in the national market;

g) Contribution towards the process of Lat in American integration;

h) Technical features of the project, its management and administration; and

i) Any other circumstances considered pertinent by the Council to ensure that the investment conforms to the economic and social development programs and to the advisability of 


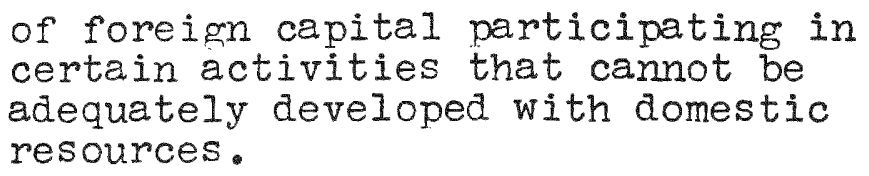

Preference should be given to the review of such investments as may result in increasing or diversifying exports.

In reviewing foreign capital investment applications, the National Planning Department shall ensure that the appropriate projects meet the economic development priorities of the country, in accordance with the following criteria:

a) Association of national capital and investors;

b) Contribution of the investment to subregional and Latin American integration processes;

c) Net effect of the investment on the country's balance of payments;

d) Contribution of the investment to improving the level of employment in the country;

e) Contribution of the project to the country's technological, administrative and commercial development, and participation of national personnel in its management;

f) Degree of initial or subsequent utilization of raw materials and of parts or items manufactured at present or to be manufactured in Colombia;

g) Effect of the project in the sector concerned;

h) Proportion between the imported capital and the requirements of fixed investment and working capital;

i) Degree of market competition of the line of products in question. It is understood that foreign investments shall not be approved in activities adequately attended by existing enterprises. 
The National Planning Department shall approve foreign capital investment projects involving the purchase of stock, shares or interest held by national investors only if the imminent bankruptcy of the enterprise in which the investment is to be made is substantiated.

The approval of any foreign investment is subject to conditions and requirements based on technical and political criteria applied by the Administration in evaluating the investment project, and on express legal restrictions or prohibitions.

Terms for Deciding on Approval or Rejection

The National Planning Department shall issue a reasoned opinion on the applications, within sixty days from the date the presentation of the required documents is completed. Such opinion shall be officially made known to the investors. The said term may be extended by means of a National Planning Department decision for up to sixty additional days when so required due to specially complex project conditions. Any applications not resolved within the above terms shall be deemed to be approved.

The National Council for Economic and Social Policy may simplify the proceedings for evaluating foreign capital investments in areas of evident importance or by reason of their small amount.

Terms for Making the Investment

"Pursuant to the provision of Article 107, 
Decree 444 of 1967, the foreign investment authorization granted by the National Planning Department shall in each case set forth the term in which the investment must be made. Investments not made within the term so stated shall require a new authorization." 2

Review of the National Planning Department's Decision

The National Council for Economic and Social Policy may, at the investor's request, review the opinion issued by the National Planning Department. This department may, at its discretion, approve or reject any direct foreign investment application. That is why such administrative action is considered to be of discretional nature. Failure to comply with the obligations indicated in the approval of the investment gives rise, to forfeiting the approval and the perogatives deriving therefrom. On the other hand, the fulfillment of the requirements set forth under the act of approval guarantees its being kept in force.

The National Planning Department considers that the Administrative act of authorizing the investment, grants the foreign investor the right to import foreign currency, convert some and carry out the investment, provided the recipient enterprise is willing to accept the foreign investment or is legally or contractually bound to do so. The right to register the foreign investment with the Exchange Office of the Bank of the Republic

$$
\text { 2 Ibid., p. } 46 \text {. }
$$


depends on the fulfillment of the conditions established under the authorization.

The burden of fulfilling such conditions falls on the foreign investor rather than on any third parties, on whom such fulfillment may in fact depend, as would be the case where the recipient enterprise's consent is required, or where the investment is to be made in a specific enterprise which must in turn agree to make exports for a given amount during a specified period.

C. OBLIGATION TO REGISTER THE INVESTMENT

Every direct foreign investment shall be registered with the competent national agency together with the agreement determining the conditions of the authorization. The amount of the investment should be registered in a freely convertible currency.

Competent National Registration Agency

Once approved by the National Planning Department (NPD), the foreign capital investments shall be registered at the Exchange Office.

Also registered with such office shall be the movement of investments, including additional foreign investments, reinvestments of profits entitled to be remitted abroad, remittance of profits and reimbursements of capital.

The Exchange office shall issue regulations as to the form and terms of the registration ordered and, 
If necessary, shall determine the procedure for assessing the value of investments not made in foreign currency, such as those represented in machinery and equipment.

"Article 120: Foreign capital invested after June 17, 1957, shall be registered with the Exchange Office. The registration constitutes an essential requirement for the continued remittance of profits and reimbursement of capital abroad.

Article 121: The Exchange office may reject any registration applications submitted under the preceding Article when the evidence presented to substantiate the authenticity of the investment and the data relative to its movements are insufficient." 3

\section{Currency for Registration Purposes}

The registration of foreign investments and their movements must be made in the currency adopted by the Monetary Board and no readjustment or revaluation thereof shall be allowed.

The Exchange Office of the Bank of the Republic may register foreign investments in the following currencies in addition to the U.S. dollar: German mark, Belgian franc, French franc, Dutch florin, Pound sterling, Italian lire, Danish crown, Swedish crown, Swiss franc, Japanese yen and Venezuelan bolivar.

\footnotetext{
3 Gilberto Arango, Estructura Económica Colombia, (Bogotá, Ediciones Colibn, 1981), p. 50 .
} 
Data to be Contained in the Application

To secure the registration referred to in Article 120 hereinabove, an application must be filed with the Exchange Office, containing the following data:
a) Name of the investor;
b) Amount of the original investment, according to the method of calculation fixed by the National Council for Economic Policy;
c) Amount of the foreign investments in addition to the original investment, determined in the same manner;
d) Amount of reinvestment of profits;
e) Amount in foreign currency of the profits remitted abroad;
f) Portion of the capital reimbursed abroad;
g) Any other data required by the Exchange

\section{NET VALUE OF THE INVESTMENT}

The net foreign currency value of the investment is comprised of the capital originally imported, any additional foreign investments, and reinvestment of profits entitled to be remitted abroad, minus any capital reimbursements, all of this pursuant to the data registered with the Exchange Office. The net foreign currency value of investments made in Colombia prior to March 22 , 1967 shall be estimated as follows:

1 - In companies legally incorporated abroad, which have obtained an operating permit in Colombia, the net value as of December 31 st 
of each year shall be comprised of the following factors:

a - The initially "assigned Capital," $i . e$. , the amount of the foreign contribution shown on the appropriate document of incorporation, converted into dollars at the rate of exchange applicable to these transactions in effect on the date of such document.

b - Any increase in this initially assigned capital shall be calculated at the applicable rate of exchange in effect on the date of legalization of such increases;

c - The estimated dollar surplus (or deficit), at the average annual rate of exchange of the applicable market during the year when the profit (or loss) which gave rise to the appropriate exchange of the surplus (or deficit) was generated;

c Capital availabilities in the form of assets, currency or services remaining in the Home office account during the fiscal year to which the profits apply, upon evidencing of this circumstance to the exchange office, in agreement with such documents as such office required.

e Capital reimbursements made prior to March 22, 1967, and those authorized from such date onward.

E. TRANSFER OF PROFITS

The owners of a direct foreign investment shall be entitled, upon authorization by the competent national agency, to transfer abroad, in freely convertible currency, the proven net profits originating from their direct foreign investment of up to $20 \%$ per annum of such investment. The competent national agency may also authorize 
the investment of any surplus of distributed profits, in which case it shall be deemed to be a direct foreign investment.

According to Decree Law 444, March 22, 1967, Article 115, the registration of the investment at the exchange office shall entitle its owner to:
a - Remit abroad the profits thereof within the limits provided hereunder and under resolutions of the National Council for Economic Policy in force on the date of the registration.
b - Reimburse the principal, up to the amount actually imported and that of the rein- vestments of profits entitled to be remitted abroad, in the event of total or partial disposal of the assets, stocks or interest or in case of invest- ments subject to depletion.

\section{Rate of Exchange}

Remittances convening profits on foreign capital invested in Colombia and reimbursement of said foreign capital shall be made through the capital market, at the rate of exchange in effect in said market at the time of such remittances. The capital market rate shall also apply to purchases made by the Bank of The Republic of foreign currency originating from foreign investments. The conversion of any amounts that a foreign investor is entitled to remit abroad shall be made at the rate of exchange in effect on the date of the remittance. 


\section{F. REINVESTMENT OF PROFIT}

The reinvestment of profits earned by foreign enterprises shall be considered new investment and can only be made upon prior authorization and registration. The Colombian Government may allow reinvestments of. profits earned by foreign enterprises without any particular authorization, if such amounts do not exceed annually, $7 \%$ of the capital of the firm in question. The obligation to register remains unchanged in these cases.

\section{G. INVESTMENT OF EXCESS PROFITS}

"Article I. For purposes of Subsection 3, Article 10, Decision 103 of the Cartagena Agreement Commission Incorporated in Colombian legislation by means of Decree 170 of 1977.14 The National Planning Department may grant the status of direct foreign investment to the capitalization of excess profits over and above the limits on transfers abroad, generated before or after the effective date of the resolution, provided the enterprises receiving the investment, of such surpluses use at least $50 \%$ of the new investment to purchase bonds of the Industrial Development Institute (Instituto de Fomento Industrial).

The purchase of these bonds shall be made by the enterprise receiving the investment of surplus profits within 30 days from the approval of such investment. In

\footnotetext{
4 Banco de la República, Guía para el Inversionista, (Bogotá, Editorial Panorama, 1974), p. 121.
} 
special cases, the National Planning Department may grant a longer term for the purchase of bonds.

The bonds to be issued by the Industrial Development Institute shall:
a) Bear the name of the holder b) Earn an interest rate of $15 \%$ annually,
payable semi-annualiy
c) Have a maturity of 5 years

\section{H. RE-EXPORTATION OF CAPITAL}

The foreign investor shall be entitled to re-export invested capital upon sale of his stock shares or interest to national investors, or upon liquidation of the enterprise. The sale of stock shares or interest by one foreign investor to another must previously be authorized by the competent National agency and shall not be deemed to be a re-exportation of capital. A subregional investor shall be entitled to re-export the invested capital upon sale of his stock shares or interest to National or subregional investors, or upon liquidation of enterprise.

According to Decree Law 444, March 22, 1967, Article 115, the registration of the investment at the exchange office shall entitle its owner to:

a) Remit abroad the profits thereof within the limits provided hereunder and under resolutions of the National Council for Economic Policy in force on the date of the registration;

b) Reimburse the principal, up to the amount actually imported and that of the reinvestments of profits entitled to be 
remitted abroad, in the event of total or partial disposal of the assets, stocks or interest or in case of investments subject to depletion.

c) In cases other than those contemplated under the preceding subsection, to reimburse moderate amounts for amortization of investments, pursuant to the National Planning Department's decisions at the time it authorizes the investment and in comformity with the criteria set by the Council for Economic Policy.

It is understood that in no case shall authorization be given to purchase foreign currency for capital reimbursements in amounts in excess of the net foreign currency balance of the investment in question.

To decide whether or not a Colombian corporation is entitled to apply for the authorization necessary for any transfer of its stock by one foreign investor to another, it shall in each case be required to examine the provisions of the company's by-laws in accordance with any special authorization received for the purpose by the applicant from the persons concerned.

The individuals representing the assignor or assignee investors for any purpose in Colombia shall substantiate the legitimacy of such representation according to the applicable regulations, such as Article 408 of the Commercial Code, and Articles 65 and 259 of the code of Civil Procedure.

In regards to the effect of the assignment authorization by the National Planning Department, it should be 
taken into account that such authorization does not have the virtue to actually assign the ownership of the stock in question. Such assignment becomes effective through the registration thereof in the Stock Register, by means of a written order by the assignor. This is independent from the assignment authorization granted by this Department, and, without prejudice to the exchange consequences, it would be at least controversial whether the absence of the latter affects the validity of the assignment between the parties and vis a vis the corporation.

Accordingly, a hypothetical defective representation of the parties in the administrative processing of the assignment application would not infringe "the civil and commercial law of Colombia on transfers of stock in a Colombian Corporation," provided the seller is otherwise duly represented under such laws by the person who gives the written order of assignment.

Finally,"...in view of the provision of Article 406 of the Commercial Code and of these Departments territorial jurisdiction, the processing of the authorization and the authorization itself, as well as the transfer registration of the stock of a corporation organized in Colombia, cannot take place abroad but on Colombian territory only, even though the holders or owners of the stock be foreign investors." 5

5Departamento Nacional de Planeación, op. cit., p. 63. 
Re-exportable capital is understood to mean capital formed by the amount of the initial direct foreign investment, registered and actually incurred, plus any reinvestments made in the same enterprise, substracting net losses, if any. In cases where there is participation of national investors, the above provision should be understood to be limited to the percentage of the direct foreign investment on the reinvestment made and on the net losses.

\section{Exportation of Capital Gains}

In the case of Iiquidation of the enterprise, the number resulting between the real value of the net assets and the re-exportable capital, shall be considered to be a capital gain which can be transferred abroad upon payment of the applicable taxes.

A foreign investor shall also be entitled to transfer abroad the amounts obtained as a result of the sale of his stock, shares or interest upon payment of the applicable taxes.

I. CONTROL OVER THE INVESTMENT

The control of the performance of obligations incurred by foreign investors shall be entrusted to the agency which registers the investment, in coordination with the competent government department or offices in each case. The competent national agency shall be responsible for:

a - Supervising the performance of commitments relative to national participation in the 
technical, administrative, financial and commercial management as well as and in the capital of the enterprise;

b - Authorizing, exceptionally, the purchase by foreign investors of stock, shares or interest in national or mixed enterprises;

c - Establishing a system of reporting and price control on such intermediate products as are furnished by the supply of foreign technology or foreign capital;

d. - Authorizing transfers abroad, in freely convertible currency, of such amounts as the enterprises or investors are entitled to remit pursuant to the national laws of the country concerned, (Colombia);

e - Centralizing statistics, accounting, informative and control records relating to direct foreign investment; and

$f$ - Authorizing license agreements for the use of imported technology and of trademarks and patents.

Juristic persons of any kind, any part of whose capital is formed by foreign investments, must provide the Exchange Office and the Exchange Control Prefecture with such data and information as may be required to verify the movement of foreign capital, and shall be subject to the supervision of the Superintendency of Corporations, with the exception of those corporations which are subject to the control of the Banking Superintendent.

"In compliance with Article 267, paragraph (d), Decree 410 of 1971, corporations whose capital is held in any part by foreign persons who have not been qualified as national investors, and which are not under the control of 
the Banking Superintendency, shall be subject to the inspection and supervision of the Superintendency of Corporations, and in consequence, shall apply for the appropriate operating permit." 6

\section{J. FOREIGN CREDIT}

Foreign credits obtained by an enterprise require prior authorization by the competent agency and must be registered with the same. Overall limits to foreign indebtedness may be authorized for specified periods. Credit agreements within such authorized overall limits shall be registered with the competent agency.

Transfer abroad made by enterprises to cover amortization and interest on foreign loans shall be authorized as per the terms of the registered loan agreement.

For foreign credit agreements executed between the home office and its affiliates or between affiliates of the same foreign enterprise, the effective annual rate of interest shall not exceed the prime rate prevailing in the finance market of the country of origin of the currency in which the transaction was registered, by more than three points. In respect to foreign credit agreements other than those mentioned before, the effective annual rate of interest payable by the enterprise shall

6Alvaro Camacho, Capital Extranjero: Subdesarrallo Colombiano, (Bogotá, Editorial Norma, 1977), p. 165. 
be determined by the competent national agency and shall be closely linked to the conditions prevailing in the financial market of the country in which the transaction was registered.

Moreover, foreign exchange transactions must be understood to cover not only those involving income or expenditures of foreign currency but also Colombian currency entering or leaving the country. Consequently, such entries and exits are subject to the exchange control provisions and may only be effected in the manner and in the cases authorized by the Monetary Board by means of general resolutions.

For exchange control purposes, the following are defined as international exchange transactions and are forbidden:

a) Bringing Colombian legal currency or certificates representing such currency into the country and taking some out;

b) Purchasing foreign currency abroad with Colombian legal currency or certificates representing the same.

Authority of the Monetary Board, Exchange Office and Exchange Control Superintendency

The Monetary Board may, by means of general regulations, forbid foreign credits originating in the execution of loan agreements and in the importation of goods, services of capital, if their objects are incompatible with the exchange and monetary policy, or limit such loans or imports should the country's foreign in- 
debtedness be excessive.

To properly carry out its functions, the Monetary Board may, through general resolutions, limit foreign credit by fixing the terms of payment of the value of imports, as well as the date from which such terms shall be counted. For this reason, consideration should be given tothe different types of imports, if this is deemed convenient.

The Monetary Board may likewise regulate the terms, credit establishments must observe in granting foreign letters of credit or in granting credit for payment of imported goods.

The Exchange Office of the Bank of the Republic must report monthly to the Monetary Board on the amount and characteristics of the country's foreign liabilities originating from imports.

"Tnder the supervisory authority granted thereto by Article 137, Decree Law 144 of 1967, the Exchange Office shall report to the Exchange Control Superintendency any cases of noncompliance with the provisions regulating foreign credit especially as regards default in remitting abroad the value of imports."?

The Exchange Office must verify noncompliance by any legally admissible means, and the Exchange Control Superintendency must penalize the infringers.

7 Superintendencia de Sociedades, Inversiones Ex$\frac{\text { tranjeras en Colombia, (Bogotá, Ministerio de Desarrallo }}{\text { Económico, 1978), p. } 72 \text {. }}$ 


\section{Financing of Projects}

In the case of loans intended to finance the installation of factories or other projects of economic or social interest, the total amount of the debt may be registered, even though a part of the foreign currency is used for the acquisition of goods or services abroad or for foreign currency payments in Colombia.

This registration must give the right to remit abroad the amounts necessary to service the loan. Such remittances replace those which might have been made for importation of goods and services included in the project and financed with the loan. Remittances covering the value of the imported goods must be made at the rate of the exchange certificate market, and the remainder at the capital market rate.

In terms of financing of imports, loans granted by credit institutions abroad to finance imports can be registered with the Exchange office only, after approval of the respective importation by the Foreign Trade Superintendency. In this case, the repayment of principal must be made through the exchange certificate market.

\section{Domestic Credit}

In respect of domestic credit, foreign enterprises will not have access to long-term credit. The terms and conditions of access to domestic short and medium-term credit will be set forth under the applicable national 
legislations, medium term being considered as credit not exceeding three years.

K - REQUIREMENTS FOR THE APPROVAL OF INVESTMENTS IN THE TOURISM SECTOR

The National Planning Department may authorize new direct investments in existing enterprises or enterprises to be established, destined for the activities "...under Division 63 of the United Nations Standard International Industrial Classification..." 8 and specifically, in restaurants, cafes and other establishments dealing in food and beverages, as well as in hotels, hostels, camps and other lodging facilities, provided the main object of the activity in question is to complement, assist, develop or promote National Tourism.

In addition, a national participation of not less than $15 \%$ of the capital must be required in any new enterprise destined for the activities previously mentioned.

When the implementation of a project affecting the tourist sector necessitates the construction or expansion of any additional infrastmucture by public entities or by other enterprises. The National Planning Department, upon clearance by the National Tourist Corporation, shall agree with the foreign investor on the proportion of the cost of such infrastructure applicable to the investor.

8Departamento Nacional de Planeación, op. cit., p. 133. 
The National Planning Department shall condition its authorization of any direct foreign investments in tourist activities, giving rise to royalties payable to other enterprises now existing or to be established in the future, who are concessionaires or affiliates of the same investor, to the approval of the pertinent contract by the Royalty Committee. 
CHAPTER VI

PROOF OF THE HYPOTHESES, CONCLUSIONS, RECOMMENDATIONS

Each hypothesis has been explored with resulting findings through the different stages of this research. These findings should prove each hypothesis to the satisfaction of those who made that assessment.

\section{FIRST HYPOTHES IS}

The International Hotel Chains Have Certain Requirements When Investing in Lat in America.

The results of the questionnaire, and the results of the personal interviews which were presented in Chapter IV, clearly show that each international hotel chain examined have their own requirements, and their own process of studying and analyzing the possibility of investing in Latin America.

Some of these companies do a more detailed survey of the potential country or city where there is the possibility of building a hotel, whereas others do not follow such a detailed analysis.

These differences in how each company approaches a potential investment are a direct consequence of the company's corporate strategy, a consequence too of whether or not the company is new in the Latin American market 'i.e., Holiday Inn or if, on the contrary, they have been in the 
market for quite some time i.e., Inter-Continental. Finally, another important reason for these differences in approaching the developing market of Latin America is the financial aspect and philosophy of the company. Some companies only go into countries where they have $100 \%$ control of the operation i.e., Hyatt International, while others such as Sheraton or Inter-Continental have a more liberal and, at the same time, flexible philosophy.

\section{SECOND HYPOTHESIS}

Colombia does not meet the basic requirements of the International Hotel chains.

The findings presented in Chapter $V$, revealed that this hypothesis in part is true and part is not. In other words, there are some requirements from the Intemational Hotel chains which are met by Colombia, but on the other hand, there are other requirements which are not met by Colombia.

In general, we can conclude that the hypothesis has been proved and it is true because there are more requirements which are not being met than those met by Colombia.

As it will be pointed out in the Conclusions, the main reason for Colombia not having more International Hotel chains is because the local investors want to invest their money in enterprises which will give them a quick return on their investment and, unfortunately, investing in a hotel entails waiting 10-15 years before getting any return on the investment. 
This problem can be solved if the Colombian Government makes loans more accessible to the local investors and to foreign investors. 


\section{CONCLUS IONS}

\section{A. Conclusions of International Hotel Companies}

Each of the international hotel companies have established their own criteria for expansion. The distinguishing differences in their approach is evident by the following facts:

1 - Several of the companies will not invest in foreign countries for fear of expropriation.

2 - Some companies have established rapid growth as their main goal and objective without consideration to demand analysis. Others are much more cautious in their expansion efforts, and consequently, lay greater emphasis on market demand.

3 - The majority of the companies examined have given complete autonomy to the local management.

4 - Some of the companies studied want to take advantage of the local opportunities that exist and diversify, while the others just want to concentrate on hotel development projects.

5 - Most of the companies prefer a management contract than a franchise contract or a 
lease arrangement. Some of the companies will not even consider a foreign project unless they will have $100 \%$ control of the management of the hotel.

6 - It is evident that some of the companies have benefited greatly by the incentives offered by some of the developing countries. These benefits range from a government guaranteeing to an international hotel company to a fixed return on investment, to total exemptions for a period of five to ten years or more.

7 - Most of the companies will support their partner hotels and prevent them from going under by advancing a loan or by signing a collateral for the loan.

8 - Most of the international hotel companies have taken extensive insurance policies to protect themselves from the liabilities ensuing from overseas hotel operations. 


\section{B. Conclusions of Colombian Laws and of Foreign Investment}

There is an unquestioned desire on the part of the Colombian Government for an increased flow of foreign investment into the country. The reason for this is a full appreciation that at this stage of its development, Colombia is not likely to achieve an adequate rate of economic growth entirely by its own means and resources. On the other hand, the total sum of direct foreign capital investment should not be disproportionate taking the national economy as a whole, since excessive dependence on foreign interests can only generate political as well as balance of payments problems.

It is essential that foreign capital should be judiciously distributed throughout the economy so as to protect the free enterprise system and acquired rights from any upheavals. While this is the general philosophy existing in Colombia today, its practical application must per force be motivated by the special circumstances of the country. In this respect, there are areas where foreign capital is more necessary than in others.

A country which practices a policy of successive devaluations can offer speculative incentives to foreign investors but--in the long run--it does not provide any guarantee in regard to the real yield of their capital. On the other hand, the maintenance of relative stability 
will give greater confidence to local and foreign capital investors who will then be able to rely on the fruits of their investment being secure.

In general, the country's economic climate has considerably improved, making Colombia more attractive to foreign investment. In this connection, it is noteworthy that Colombia has no legislation whatever preventing foreign investors from entering certain sectors of the economy. On the other hand, a foreign investment project must be submitted to the National Planning Department for prior approval and in order to ensure that it corresponds to the overall development objectives of the country. Once the necessary authorization has been obtained, there exists complete equality of rights between local and foreign entrepreneurs in regard to all economic activities.

On the other hand, there is no doubt that the existing controls on imports and international transactions do create difficulties for private enterprise, both local and foreign. These controls are not due to any dogmatic approach, but to special circumstances. They are found on an empirical and practical philosophy and on the recognition that Colombia must rely on its own possibilities. Wisdom, moderation, stability and long-term policies are among the most important ingredients for the potential health and economic development of a country. They exist in Colombia today. Private enterprise, both local and foreign, have thus been given an opportunity to 
work more effectively and this opportunity should not be missed.

The Colombian Government is indeed fully conscious of the fact that both local and foreign private investors will have to work together as a unit in order to benefit and make the investments more productive.

Finally, and in a manner to show how the Colombian Government is willing to admit foreign investment in Colombia, it has been increasing the percentage of profits allowed to be remitted outside the country by the foreign enterprises:

- Article 116, Decree Law 444 of 1967, estabIished that foreign enterprises could not remit more than $10 \%$ of the annual net value of the investment.

- Later on with Decision 24, Article 37, it determined this percentage to be $14 \%$.

- Finally, Article 10, Decision 103 of 1976, increased this percentage to $20 \%$ annually. 


\section{MAJOR CONCLUSIONS}

1 - International hotel companies are interested in Colombia, and two of them specifically have been trying to enter the market (Sheraton and Holiday Inn).

2 - The requirements by the International Hotel companies are not the reason for Colombia not having more than two international hotel companies.

3 - The main reason for international hotel companies not to be in Colombia is because local investors want a quick (2-3 year) return on their investment, and unfortunately (for both the investors and the hotel companies) investing in a hotel means waiting 10-15 years to begin getting any return on the investment.

4 - Even though Colombian Laws dealing with Foreign Investment are Iiberal, the Andean Pact, to which Colombia belongs, restricts foreign investment in Colombia. It frightens foreign investors.

5 - There is also some problems in terms of currency control, monetary restric- 
tions, also difficulties for the international hotel companies when dealing with labor laws which are tight and difficult.

6 - It is difficult to get financing in Colombia.

7 - The Hospitality Industry is not an industry of primary importance to the Colombian Government, therefore, there is a lack of interest from the government and the local investors to invest and help develop the Tourist Industry.

8 - Most of the local investors in Colombia have their money invested in fixed assets, hence, no cash flow which consequently makes it difficult to invest in hotels. 


\section{RECOMMENDATIONS}

1 - The Colombian Government should make credit easy to obtain not only to local investors but to foreign investors as well. In this manner more foreign investment will enter the country providing its widely recognized advantages.

2 - The Government and specifically the Colombian Tourism Corporation, must realize the importance and the potential that Colombia has in its Tourism Industry, support it and exploit it accordingly.

3 - The Government must create more incentives in order to attract more intermational hotel companies.

4 - Colombia must exclude the Tourism from the Andean Pact (Decision 24) as Venezuela did, in order to make it easier for international hotel companies to invest in Colombia.

5 - Of great help would be the possibility of the Tourism Corporation to guarantee the financing of hotels in Colombia. This will bring in more foreign investors, and they will feel that they have a project with less risk involved. 
6 - In terms of taxes, the Colombian Government should take action to consider the possibility of concluding with other governments bilateral agreements for the avoidance of double taxation.

7 - It would be most desirable if Colombia were to participate actively in the setting up of the Multilateral Investment Guarantee scheme. The adoption of such scheme by developing countries as well as by industrialized countries would contribute greatly to a larger flow of private capital to those areas of the world where the development needs are the greatest and the most urgent.

8 - The creation of a "Foreign Investment Promotion Board" to which the foreign investor could address himself in order to obtain guidance and advice in connection with the realization of his plans and projects. This body could centralize requests, assist the investor in his negotiations with other Governmental bodies, explaining to them the specific problems and difficulties facing the investor. 
APPENDIX A 
Mr.

Director of Operations

Dear Sir:

I am a student at Florida International University, where I am getting my Master's degree in Hotel Management.

Hereto enclosed is a questionnaire for collecting the required data about your company's requirements when investing in Latin America.

I would appreciate it very much if you fill in the questionnaire at your earliest convenience and have it mailed to the following address:

Mr. Carlos De Freitas

8500 S.W. 133 Avenue Rod., Apt. 402 Miami, Florida 33183

I will be very grateful for providing your time and thoughts to assist me in completing a good research.

Looking forward to receiving your reply, as soon as possible, and thanking you in advance for your assistance.

Sincerely yours,

CARLOS ALBERTO DE FREITAS 


\section{QUESTIONNA IRE}

I. Reasons for Developing Hotels Overseas

1 - What are the primary considerations for going overseas? Is it because no financial investment is required, or very little?

2 - If certain areas of the world are selected, what criteria is used to determine if this city or country will provide the markets for the hotels to achieve a desired occupancy percentage?

3 - Do tax considerations and rebates offered in foreign countries play a major role in your decision to build a hotel in that country? To what extent?

4 - Paying no U.S. taxes on foreign earnings, does this play a significant role in building hotels in those countries where the hotel industry has been awarded a tax holiday? To what extent?

5 - Often, investment is guaranteed by the U.S. Department of Commerce and financed by the World Bank--hence, no risk--is this a consideration in going overseas?

6 - What criteria is used to determine the long mun economic possibilities in a country? 
II. Criteria Used for Development Overseas

A. Financial

1 - How is the project evaluated-if it is going to prove viable or not?

2 - Because of legal requirements in a foreign country, does fund flow follow legal lines?

What dictates whether one should establish

a subsidiary branch operation, joint venture or a combination of those?

3 - What steps do you take to calculate the profit potential of the partner hotel to be built in a foreign country?

4 - How does the social structure in a foreign country influence financing arrangements?

Does it make a difference whether the hotel is to operate in an industrialized economy or an agrarian economy with wide variations in the distribution of wealth? Does this factor also influence the avallability of local sources of credit?

5 - What considerations should be kept in mind during the evolution of the project when a host country dictates the amount of equity in a hotel by the International company overseas.

6 - What things are kept in mind when the financing plan for the hotel to be 
developed is considered? (Raise capital, debt and equity, etc.)

7 - What criteria is used if and when the International Hotel company makes a substantial investment in an overseas project?

\section{B. Stability and Corporate Strategy}

I - How does your company evaluate a country's social and political climate? Criteria used?

2 - Does your company want to expand into a country which promises long term or short term growth? Countries which have existing markets for your services or countries which will provide for anticipated markets?

3 - What are your company's objectives? To build fine, luxurious hotels in key metropolitan, resort and destination cities around the world; or to build moderately priced or lower priced hotels to take advantage of a wide market range?

4 - What are the long and short term objectives as far as operating hotels around the world? 
III. Relationships with Local Govemments and Restrictions Imposed

1 - How is the investment in the International Hotel Company affected if only a percentage of earnings is allowed to be remittable by the local government? If the local government comes out with stringent regulations, how does the International Hotel Company deal with this situation?

2 - When the loan is guaranteed by the local govermment, is this sufficient for the International Hotel Company to pursue the project?

3 - What is the extent of analysis done on local government attitudes towards investment, its long term goals, and the priorities laid down?

4 - A local government may lay down restrictions that determine if the prices of certain services can be increased, and also if a foreign company can invest in a subsidiary. How extensively are these investigated, and how do these affect your decision to go into a country? 
IV. Intentions to Invest or be in Colombia

1 - Does your company have intentions on being in Colombia? Why?

2 - Does your company view Colombia as a country with a high or low risk factor? Would the risk factor influence the company's decision as to whether or not to invest in Colombia?

3 - Does your company view Colombia as a key country in South America because of its geographical location? If so, how important is this aspect in making an investment decision? Why?

4 - Does your company view Colombia as a country with a good Tourism potential?

5 - If applicable, what are the difficulties that have not allowed your company to enter into the Colombian market? 
APPENDIX B

DECREE LAW 444-MARCH 22, 1967 


\section{A PPENDIX B}

DECREE LAW 444-MARCH 22, 1967

CHAPTER VIII

Control of Capital

Article 105: The rules of this Chapter shall be applicable to foreign capital investments in Colombia, to foreign currency credits granted to individual or entities residing in this country, and to the investments or loans that the latter may make or grant to individuals or organizations abroad.

\section{SECTION ONE}

\section{Investment of Foreign Capital}

Article 106: Foreign capital investments in established sented by the following: or in proposed enterprises may be repre-

a) Import of machinery and equipment covered by non-reimbursable import licenses, as a capital contribution:

b) Import of foreign exchange for sale to the Bank of the Republic to be invested in national currency as a direct capital contribution or for the acquisition of rights, shares or other valuables, and

c) Other, as determined by the National Council of Economic Policy by means of general Resolutions.

Article 107: Any proposed investment of foreign capital in the country shall require the approval of the (National) Planning Department.

Any substitution of the original investment shall likewise be subject to the approval of this Department.

The (National) Planning Department shall study, within the terms fixed by the National Council of Economic Policy, the proposed investments, as the case may be, in accordance with the criteria herein set forth and those laid down by said Council through general Resolutions. 
Any applications which have not been resolved within the period fixed by the regulations of the Council shall be regarded as approved (see Article 6 of Resolution 1, 1967).

Article 108: The National Council of Economic Policy may exempt certain types of investments from the requirement of the preceding Article, due to their evident importance for the economic and social development of the country or their small value.

Article 109: The application for approval of foreign capital investments filled for the consideration of the (National) Planning Department shall contain the following data:

a) Name and domicile of the investor;

b) Purpose of the investment;

c) Amount of the investment and, if necessary, the overall value of the project;

d) Period in which the remittance of profits abroad is expected to start; and,

e) All other data determined by the National Council of Economic Policy through general Resolutions.

Article 110: The National Council of Economic Policy shall determine the criteria to be applied by the (National) Planning Department for the study of the foreign capital investment applications, taking into account the following factors;

a) Contribution of the investment to the country's employment level;

b) Net effect of the investment on the balance of payments ;

c) Degree of initial and subsequent utilization of national raw materials and parts or elements manufactured or to be manufactured in this country.

d) Proportion between the capital imported and the fixed investment requirements and working capital needed by the respective enterprise;

e) Participation of national capital and national investors; 
f) Degree of competition in the market for the respective product;

g) Contribution to the process of Latin American integration;

h) Technical features of the project, its management and administration; and,

i) All other circumstances which the Council may deem desirable to ensure that the investment will conform with the programs of economic and social development and with the advisability of connecting foreign capital to certain activities which can not be adequately carried out with internal resources only.

Paragraph: Preference shall be given to investments which of exports. would result in the increase or diversification

Article 111: Should the purpose of the foreign investment be to make direct capital contributions to already existing enterprises, the (National) Planning Department shall take into consideration, among the criteria mentioned in the preceding Article, those which would be applicable to this type of investment.

Article 112: The National Council of Economic Policy may determine that projects of special importance for the development of the country be submitted for the consideration of national and foreign investors so that investment proposals may be filed and, among them, the most convenient to the national interests be selected.

Article 113: Foreign capital investments shall be registered at the office of Exchange, once they are approved by the (National) Planning Department.

The movement of the investments, including additional foreign investments, re-investment of profits entitled to remittance abroad, remittance of profits and capital reimbursement, shall also be registered at said office.

The Office of Exchange shall regulate the manner and terms of the registrations herein provided for and shall determine, if necessary, the procedure to be followed for assessing the value of investments not made in foreign currencies, such as those represented by machinery and equipment.

Article 114: The registration of foreign investments and their movement shall be made in the foreign currency adopted by the Monetary Board and no readjustment or re-evaluation will be allowed. 
Article 115: The registration of the investment by the investor) Office of Exchange shall entitle (the investor) to the following:

a) Remittance of profits abroad within the limits set by this Statute and by the resolutions of the National Council of Economic Policy which may be in force at the time of the registration;

b) Reimbursement of the principal for up to the amount actually imported plus the amount of profits reinvested entitled to remittance abroad, in the event of total or partial disposal of the goods, shares or respective rights; or in the case of investments subject to depletion, such as those made in exploitation of mineral deposits, all in accordance with the provisions of Article 12 of this Statute;

c) Reimbursement, in cases other than those contemplated by the preceding sub-section, of moderate amounts for investment amortization, as dictated by the (National) Planning Department at the time of the asproval of the investment and in line with the criteria set forth by the Council of Economic Policy.

Paragraph: It is understood that at no time shall the purchase of foreign exchange be authorized for the reimbursement of capitals for amounts exceeding the net balance in foreign currency of the corresponding investment, as defined in the last paragraph of the following Article.

Article 116: Only those profits that were actually produced by the foreign investment may be remitted abroad. The office of Exchange and the Prefecture of Exchange Control shall supervise the exercise of this right.

Remittances abroad of foreign capital profits may not exceed $10 \%$ per annum, computed on the basis of the net value in foreign currency of the investment. (This percentage was increased to $14 \%$ by Resolution 7, 1968 of the National Council of Economic Policy, and increased again to 20\% annually by Article 10, Decision 103 of 1976).

The net value in foreign currency of the investment is made up of the capital initially invested, additional foreign investments and profit reinvestments entitled to remittance, less the capital reimbursements, all in accordance with the amounts that have been registered by the Office of Exchange. 
Article 117: (Substituted by Article 117 of Decree 444, 1967, as follows:)

In spite of the provisions of the foregoing Article, the National Council of Economic Policy may increase in a general way or for specific branches of production the maximum percentage therein stipulated for the remittance of profits, in the light of conditions prevailing in the international capital market.

The council may also authorize larger percentages of profit remittance in the case of certain investments which are specially important for the national economy of Which imply special risks, or which, by their nature, yield a delayed profit.

Article 118: The right to remit profits abroad from capital investment in the country shall become effective on the date the company starts production or the capital invested yields profits.

If over any one period profits are remitted for an amount below the authorized percentage, the difference may be remitted in subsequent periods, without exceeding an additional $3 \%$ per annum.

Foreign capital investors may choose to reinvest, with the same rights of the initial capital, any remittable profits which have not been remitted abroad.

Article 112: Duly registered foreign capitals invested prior to June 17,1957 shall not require further registration, but any data or information dealing with them must be supplied at the request of the Office of Exchange.

Article 120: Foreign capital invested in the country with the office of Exchange. 1957 , must be registered

This registration shall constitute an indispensable requisite to continue remitting profits abroad as well as for the reimbursement of capital.

Article 121: The Office of Exchange may reject applications for registration filed pursuant to the preceding Article when sufficient evidence is not given to it as to the authenticity of the investment and the data relating to its movement.

Article 122: In order to obtain the registration required by Article 120 above, an application must be filed with the office of Exchange showing the
following information: 
a) Name of the investor;

b) Value of the initial investment accoraing to the calculation system indicated by the National Council of Economic Policy;

c) Value of the foreign investments in addition to the initial investment, calculated in the same manner;

d) Value of the reinvestments of profits.

e) Amount in foreign currency of the profits remitted abroad;

f) Portion of capital reimbursed abroad; and

g) AII other information required by the office of Exchange.

Article 123: The rules of this statute as to remittance of profits and reimbursement of capital

shall also be applicable to capitals registered prior to June 17, 1957 and those registered pursuant to Article 120 above.

The terms and conditions under which the remittance corresponding to amortization or reimbursement of these capitals may be made shall be regulated by the National Council of Economic Policy.

Article 124: Remittance of profits from foreign capital invested in Colombia and of its reimbursement shall be made through the capital market at the rate prevailing at the time of the remittance. The capital market rate shall also be used for the purchase by the Bank of the Republic of exchange corresponding to foreign investments.

Article 125: (Substituted by Article 10 of Decree 688, 1967, as follows:)

Legal entities of any nature whose capital is partly made up of foreign investment shall supply to the office of Exchange and to the Prefecture of Exchange Control the data required to verify the movement of foreign capital and they. shall be subject to the supervision of the Superintendency of Corporations, except when they are already supervised by the Banking Superintendent. 


\section{SELECTED BIBLIOGRA PHY}

Books

Agudelo, Hernando. La Política del Ministerio de Desarrol1o. Vol. I. Bogota: Ministerio de Desarrollo Económico, 1972.

Arango, Gilberto. Estructura Económica Colombiana, 4th, ed., 7th reprint ed., Bogota': Ediciones Colibri, 1981.

Banco de la República. Guía para el Inversionista, 10th ed., Editiorial Panorama, Bogota, 1974.

Camacho, Alvaro. Capital Extranjero: Subdesarrollo Colombiano, 3rd ed., Editorial Norma, Bogota', 1977.

Carlson, Edward. International Growth of Western International Hotels. University of Washington Business Review, Spring 1970, Seattle, Washington.

Corporac ión, Nac ional de Turismo. Reglamentación Hotelera. Bogotá: Ministerio de Desarrollo Económico, 1978.

Cox III, Eli. Marketing Research: Information for Decision Making. The University of Texas at Austin: Harper \& Row Publishers, 1979.

Departamento Nacional de Planeación, Foreion Investment in Colombia: Basic Rules, Ist ed. Editorial Presencia, Bogota! Colombia, June 1980.

Empresa Colombiana de Turismo S.A., Evaluación Económica de la Industria Hotelera Nacional, Junio 1977.

Horwath and Horwarth International. Worldwide Lodging Industry. Twelfth Annual Report on International Hotel Operations, 1982 edition.

International Union of Official Travel Organizations, Compendium of Financial and Fiscal Schemes for Development. Geneva, Switzerland, August 1969.

Krause, Jud and Joseph. International Tourism and Latin American Development, Bureau of Bus iness Research, The University of Texas at Austin, Austin, Texas, 1973.

Lundberg, Donald. The Tourist Business, 2nd ed. Jule Wilkins on ed., Cahners Books. 
McIntosh, Robert. Tourism: Principles, Practices and Philosophies. Grid, Inc., 1972.

Michael, Peters. International Tourism. Iondon: Hutchinson \& Co.., Lta.., 1969.

Mikesell, Raymond. Inversiones Extranjeras en America Latina. University of Virginia. Panamerican Union, Washington, D.C., 1956.

Moreno, Diego, Resultados de una Política de Desarrollo. Bogota', Editorial Norma, 1976-1978.

Naciones Unidas. Inversiones Extranjeras en America Latina Departamento de Asuntos Economicos y Sociales, New York, 1955.

National Geographic Picture Atlas of Our World. Washington, D.C.: National Geographic Society, 1979 .

Pacto Andino: Su historia, su desarrollo, su futuro. Tomo I. Bogota': Editorial Gloca Pedagogica Didactica, 1973.

Rueda, Bernardo. A Statement of the Laws of Colombia in Matters Affecting Business, 3rd ed. Pan American Union, Washington, D.C., General Secretariat Organization of American States, 1965.

Rueda, Bernardo. Supplement: A statement of the Laws of Colombia in Matters Affecting Business, 4th ed. Pan American Union, Washington, D.C., General Secretariat Organization of American States, 1969.

Superintendencia de Sociedades. Inversiones Extranjeras en Colombia. Ministerio de Desarrollo Economico, Bogota', 1978.

\section{Magazines or Journals}

"A Hotel Chain Rises to Rival the Giants," Business Week, September 19, 1970.

"Birth of International Hotel Company," Intercontinental Hotels News, April 1971.

"Colombia-A Statistical Survey of the Intermational Economy." Colombia Today. Vol. 16, No. 7 New York, 1981.

"Financing International Operations," American Management Association, New York, 1965. 
"Five Member Nations Liberalize Import Policies and Remove Traditional Barriers to Foreign Investment," Industry Week, November 16, 1981.

"Foreign Investment Trends in Colombia." Colombia Today. Vol. 14 No. 11 New York, 1979.

"Hyatt Corporation-Geared for the 21st Century," Institutions/Volume Feeding, October 1974.

"Industria en Inminente Crisis," El Espectador, Bogotá, Febrero 21, 1983.

"International Hotel Development," The Cornell Hotel and Restaurant Administration Quarterly, February 1967.

"ITT Learns the Hotel Business," Business Week, November 3, 1973.

"Mecanistimos de la Integración Andina," Gmupo Andino, Junta del Acuerdo de Cartagena. Unidad de Communicaciones. Lima, Perú, 1977.

"News from all Around the World," Sheraton World, Volume 6, No. I, March 1974.

"Problems in Going International," The Comell Hotel and Restaurant Administration Quarterly, February 1969.

"Sheraton Corporation-Expansion Plans," Hospitality, December 1969.

Statler Lectures. Presented at the University of Massachusetts. Department of Hotel, Restaurant and Travel Administration, 1971, pp. 59-66.

"Tax Implications in Foreign Countries," Inn's Review, June 1964.

"The Colombian Economy 1981-1982," Colombia Today, Vol. 16 No. 11 New York, 1981.

The Comell Hotel and Restaurant Administration Quarterly. School of Hotel Management. Comell University, August 1979, 1980, 1981.

"The Private World of Pritzkers," New York Times, October 1973.

"Top Hotels in Every Country," Institutions/Volume Feeding, September 1971. 
"Top 100 World Hotel Chains Note Sales and Profits." Hotels and Restaurants International, June 1982.

"Tourism in Colombia," Colombia Today, Vol. 15 No. 2, New York, 1980.

"U.N. Report on Transnational Hotel Chains," Service World International, February 1981.

\section{Interviews}

Crespo, Nicolás. The Sheraton Corporation, Miami, Florida, Interview March 22, 1983.

Hummer, Karl. Holiday Inn, Miami, Florida, Interview May $19,1983$.

Johnson, John. Laventhol and Horwarth, Miami, Florida, Interview April 1, 1983.

Menendez, José. Hilton International, Bogotá, Colombia, Interview June 21, 1982.

Stein, Michael A., Laventhol and Horwarth, Miami, Florida, Interview April 1, 1983.

Tumer, William K. Inter-Continental Hotels, Miami, Florida, Interview November 19, 1982.

Valencia, Guillermo. Hotel Tequendama Inter-Continental, Bogotá, Colombia, Interview July 27, 1982.

Zabala, José L. Bogotá-Hilton International, Bogotá, Colombia, Interview May 25, 1982. 
VITA

TITLE OF THES IS:

A STUDY TO DETERMINE THE BASIC REQUIREMENTS OF INTERNATIONAL HOTEL CHAINS WHEN INVESTING IN LATIN AMERICA, AND AISO TO ANALYZE IF COLOMBIA MEETS THESE BASIC REQUIREMENTS. FULL NAME:

Carlos Alberto De Freitas Liévano PLACE AND DATE OF BIRTH:

Bogotá, Colombia; November 13, 1958 ELENENTARY AND SECONDARY EDUCATION:

Elementary and secondary school, Bogotá, Colombia Rosario High School, Bogotá, Colombia

UNIVERS ITIES:

Los Andes University, School of Business Administration, Bogotá, Colombia. August 1977-June 1978, Freshman year.

Miami-Dade Community College South Campus, School of Business Administration, Miami, Florida. September 1978-June 1979, Associate in Arts Degree.

Florida International University, School of Business Administration, Miami, Florida. September 1979-June 1981. Bachelor of Science, Business Administration.

Florida International University, School of Hospitality Management, Miami, Florida. August 1981-August 1983, Master of Science, Hotel Management (Candidate). MAJOR DEPARTMENT:

School of Hospitality Management PUBLICATIONS:

\section{Thes is Research}

A Study to Determine the Basic Requirements of International Hotel ohains When Investing in Latin America, and also to Analyze if Colombia Meets these Basic Requirements.

Florida International University, Miami, Florida, 1983. 